\title{
رحلة ابن فضلان بين سرد الوعي ووعي السرد
}

أ أ بيان صفوان عبد الهادي شما

باحثة دكتوراه في جامعة اليرموك

$$
\text { الأردن }
$$




\section{Abstract}

Ibn Fadlan trip between the narrative of awareness and consciousness narrative

Author addresses new worlds of self-discovery and the discovery of the other, and hopes culture and identity and reference. As for writing about the journey they are truer expression text what Aisha owner of experiments, and gained the experience and knowledge. It codifies the journey of one's choice and conscious meaning documenting specific details without the other, and thus characterized by each provision of the journey nature writer your vision unique, though varied points of the journey and the nature of places remaining lens writer that make the biggest difference and discoloration of each text turquoise featured. And the owner of the journey that we dedicate this research where diving is Ahmad ibn Fadlan bin Abbas bin Rashid bin Hammad as will be seen searching

$$
\text { رحلة ابن فضلان بين سرد الوعي ووعي بالميلغة العربية }
$$

يتناول الكاتب عوالم جديدة من

اكتشاف الذات واكتشاف الآخر، وتأمُلّ

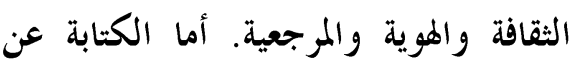

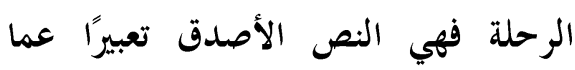

عايشه صاحبها من تجارب، وما اكتسبه من الرحان

خبرات ومعارف. فهو يدون من رحلته ما

يختاره واعيًا قاصدًا توثيق تفاصيل معينة

دون غيرها، وبذلك يتميز كل نص من

نصوص الرحلة بطابع كاتبه الخاص ورؤيته

الفريدة، وإن تففاوتت وجهات الرحلة

وطبيعة الأماكن تبقى عدسة الكاتب هي

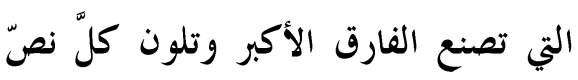

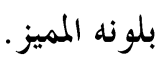

وصاحب الرحلة التي نفرد هذا البحث

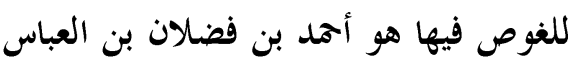
بن راشد بن ماد كما سيتضح بالبحث 


\section{مقــــدمـــة:}

انتقل الإنسان منذ العصور الأولى من مكان لآخر بكثًا عن مقومات الحياة الأساسية، ومع تطور الجختمع الإنسالي تطور مفهوم الانتقال والرحلة، وتعددت أغراض

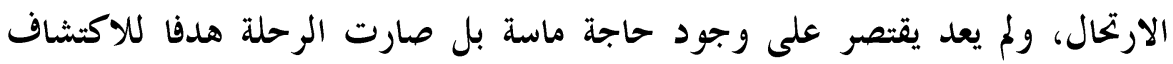

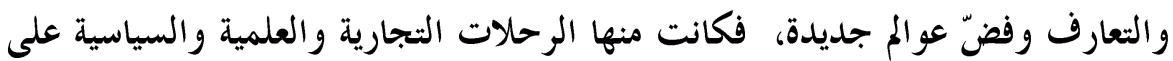
اختلاف وجهاةًا وأهدافها، والتي تمخضت عنها حاجة للتسجيل والتدوين. فكان أدب

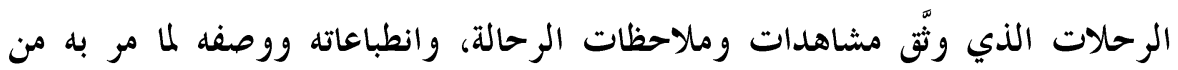

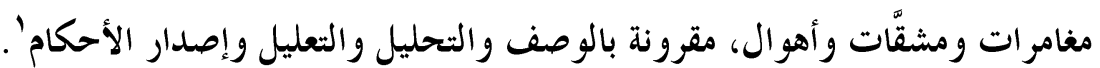

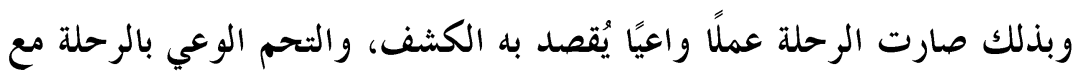

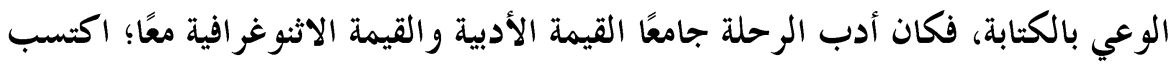
الأولى من توظيفه للسرد في نقل المشاهدات والوصف بأسلوب لا يخلو من الإمتاع والتشويق، واكتسب القيمة الاثنوغر افية من عنايته بوصف الثقافات والبجتمعات الإنسانية

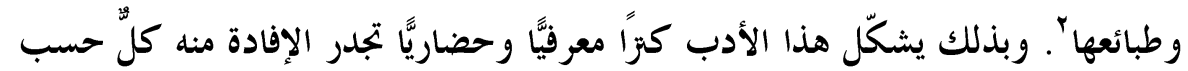
اهتمامه ومجال بحثه.

وتخلق الرحلة سياقًا خاصَّا من الوعي يلج فيه الكاتب عوالم جديدة وينفتح على مكلى

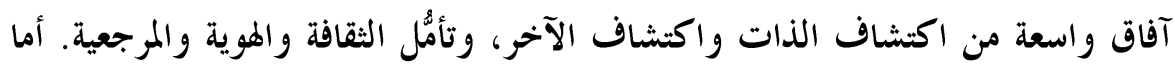

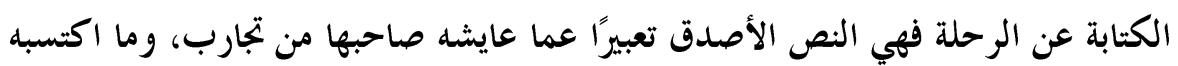

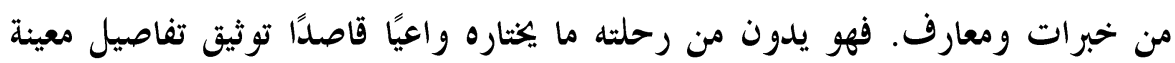
دون غيرها، وبذلك يتميز كل نص من نصوص الرحلة بطابع كاتبه الخاص ورؤيته

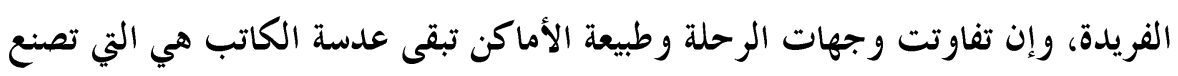
الفارق الأكبر وتلون كلَّ نصّّ بلونه المميز. 
وصاحب الرحلة التي نفرد هذا البحث للغوص فيها هو أحمد بن فضلان بن العباس بن راشد بن حماد، وهو كما تقول الرسالة مولى لفاتح مصر محمد بن سليمان. فهو

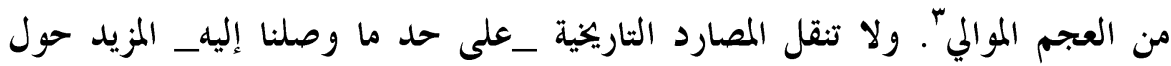

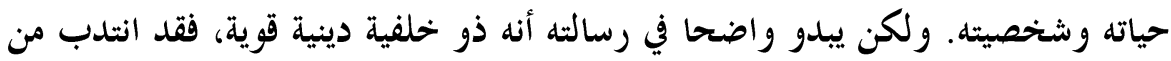

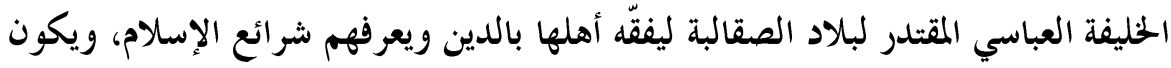

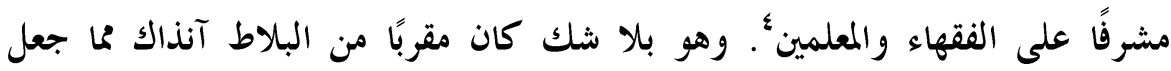

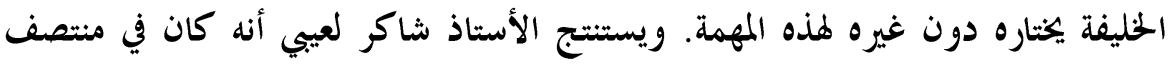

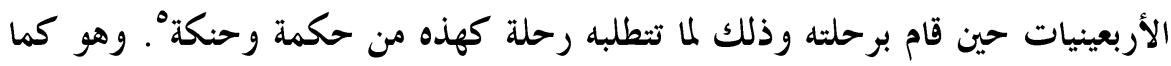
يبدو من أسلوبه الراقي والسلس رجل ذو ثقافة ميزة وحسّ مرهف، حيث تمتاز رحلته بالتر كيز على وصف الإنسان بعاداته وسلو كه، ومعتقداته وطبائعه.

وتكمن أهمية رحلة ابن فضلان في كوفا ترسم صورة عن بلاد الشمال في عصر

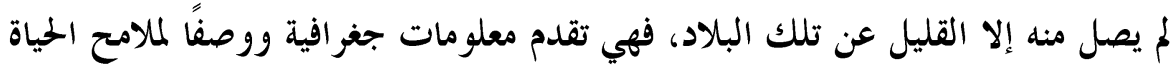

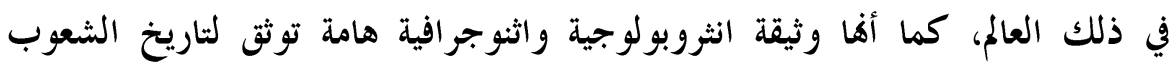

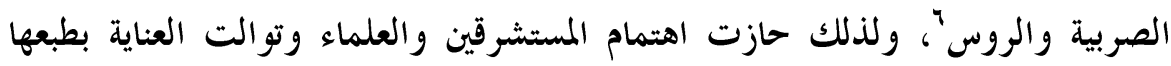
وتر بمتها.

سيقوم هذا البحث على فرضيتين رئيستين، الأولى تسعى إلى تبيان مظاهر الوعي

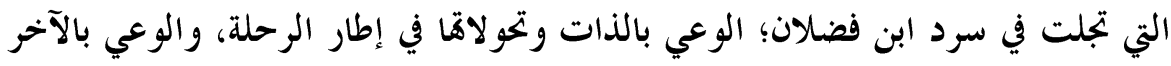
واختلافه، وتتبع مظاهر هذا الوعي التي حلها السرد. والفرضية الثانية تطرح صورة أوليّة

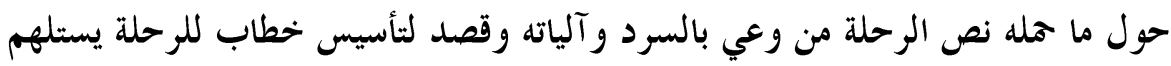
من السابق ويبني لللاحت. وإلى أي مدى كان ابن فضلان يحمل رؤية منهجية واضحة للطريقة التي يسرد بها رحلته. وكيف تجلت هذه المنهجية في النص.

يحاول هذا البحث سبر أغوار النص، وتحليل بنيته السطحية والعميقة متخذًا من ثيمة الوعي أداة لاكتشاف مكنونات النص وكنوزه. الوعي من حيث هو "محصلة عمليات ذهنية وشعورية معقدة؛ فالتفكير وحده لا ينفرد بتشكيل الوعي، فهناك الححدس 
والخيال والأحاسيس والمشاعر والإرادة والضميز؛ وهناك المبادئ والقيم ومرتكزات

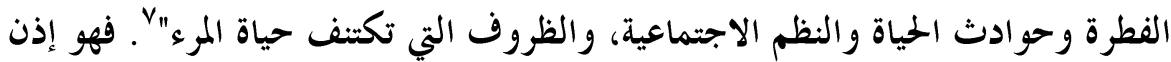

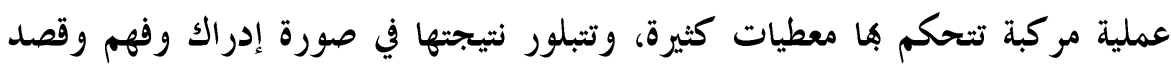

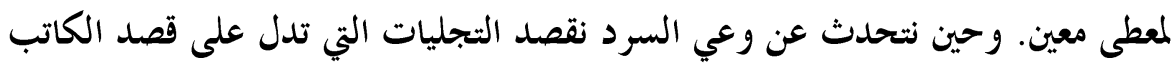

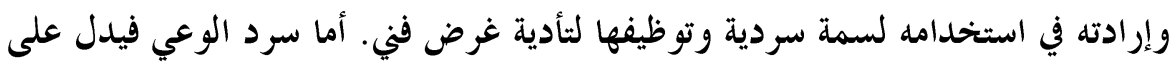
تجليات إدراك ابن فضلان وقصده لذكر معطى ما من معطيات رحلته وعيًا منه بقيمته، هذه التجليات التي حملها السرد في نص الرحلة وأفصحت عن خصوصية ابن فضلان ورؤيته.

إن الاهتمام بالوعي نابع من أهميته في فهم الإنسان واهتماماته وتفكيره، وهو في دراسة أدب الرحلة يكشف عن تجربة إنسانية ثريّة يخوضها الفرد الردما محمّلا بثقافته وتاريخه

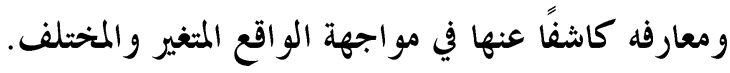

ولابد قبل البدء في تناول رحلة ابن فضلان من تعريج على أصل المخطوط وطريقة الكثف عنه:

( ) أشار ياقوت الحموي في كتابه معجم البلدان إلى رحلة ابن فضلان موردًا مقاطع منها، كقصة عجيبة عن رجل هائل الحجم وردت في رحلة ابن فضلان، ويقول

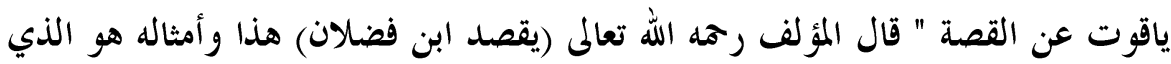

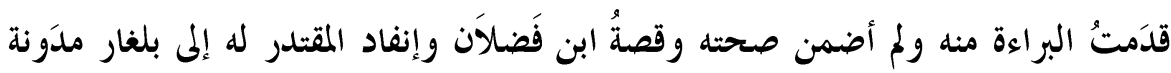

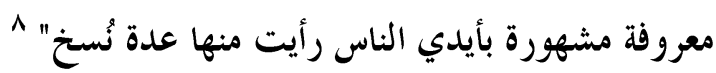

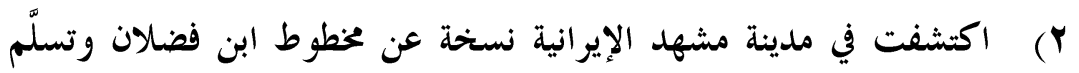
منها المعهد الآسيوي للاستشراق في بطرسبورغ ورقتين مصورتين عام ع ج 9 ا ثم وصلت

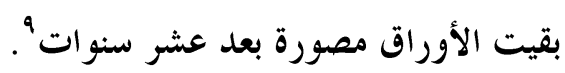

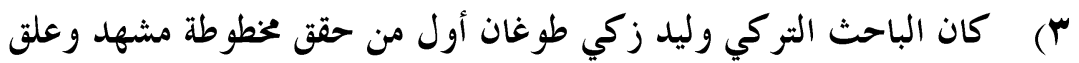
عليها، وقابلها بما جاء عند ياقوت الحموي، ونشرها بالحروف العربية والترجمة الألمانية

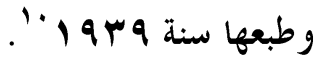


ع) وفي السنة ذاقا ترجمها المستشرق الكبيز كر اتشوفسكي إلى الروسية، وقدم

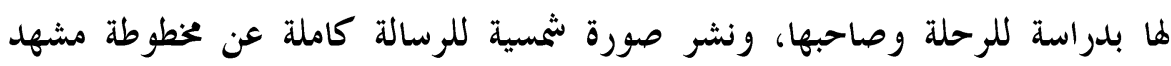

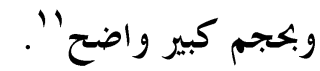

•) قام الأستاذ سامي الدهان بتحقيق المخطوط اعتمادًا على الصورة الشمسية

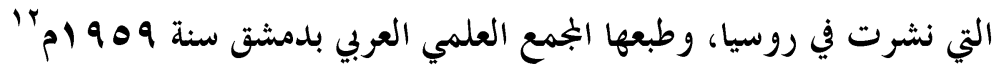

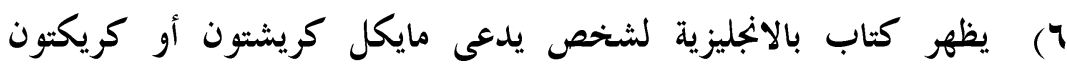

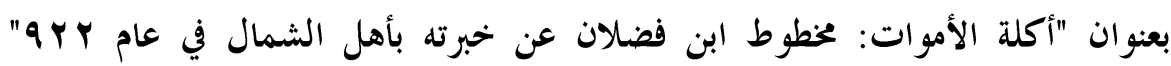

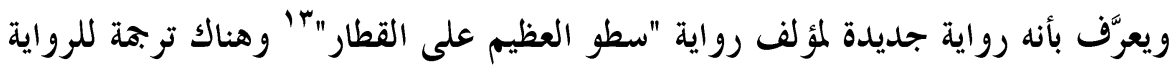

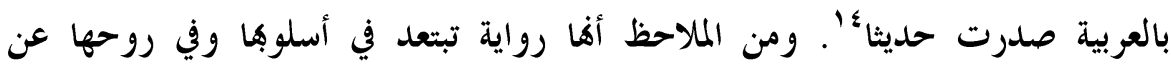

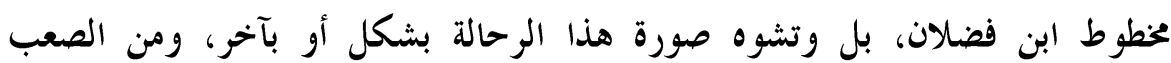

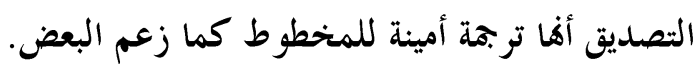

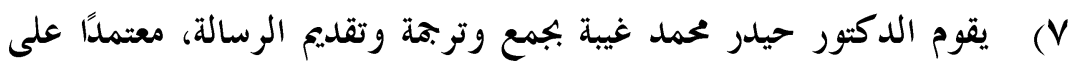

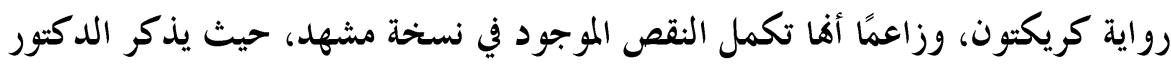

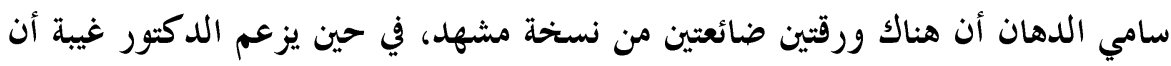
صفحات المغامرات الطوال في رواية كريكتون هي التي تسد مسد هاتين الورقتين. A أخيرًا وليس آخرًا قام الدكتور شاكر لعبي بتحرير وتقديم للرسالة اعتمادًا

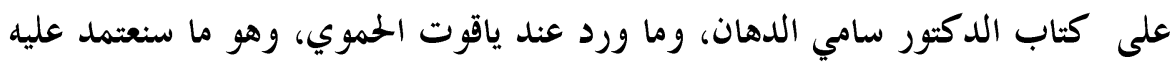
في هذه الدراسة لكون هذا العمل أكمل ما وقع في أيدينا للرسالة.

$$
\text { أولا : في وعي السرد: }
$$

// الوعي بتجربة الكتابة وأدبيات سرد الرحلة:

إننا في نص الرحلة أمام تجربتين الأولى: تجربة الرحلة التي عايشها الرحالة، والثانية:

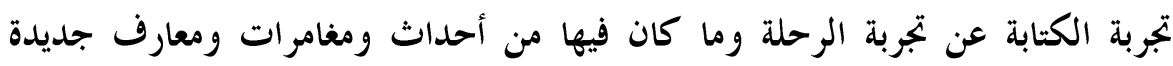
وغرائب وطرف وأقوام عايشهم الرحالة لهم طبائع وعادات مختلفة، كلها تغري الرحالة

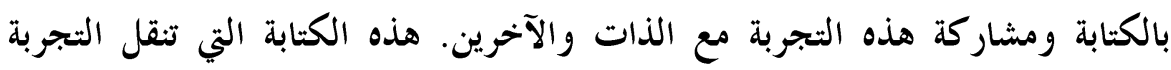




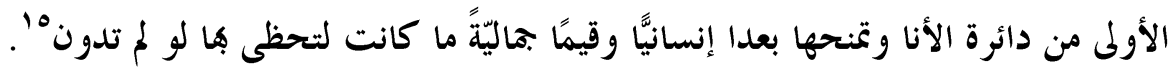
إننا إذن نتحدث عن تحربة أولى وتجربة لاحقة، ولا بلد أن تقتضي التجربة التابة اللاحقة وعيًا

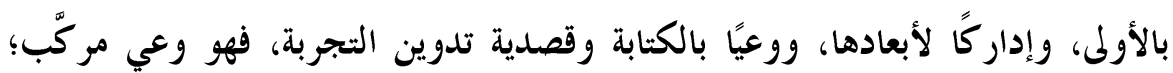
وعي بالرحلة ووعي بكتابتها.

ينبثق الوعي بالكتابة من إدراك لأهمية تدوين التجربة وتوثيقها، فالرحالة حين

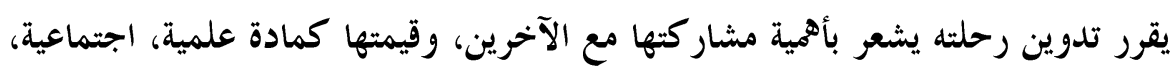

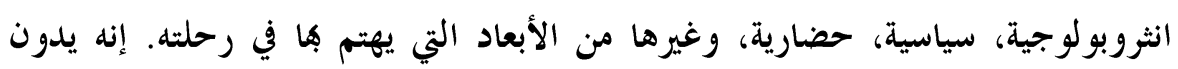

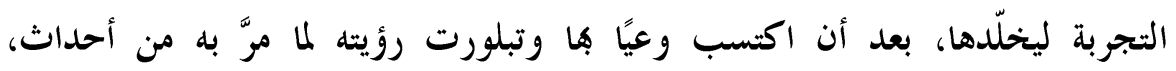

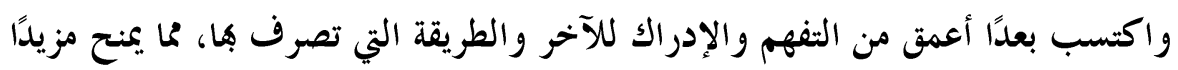

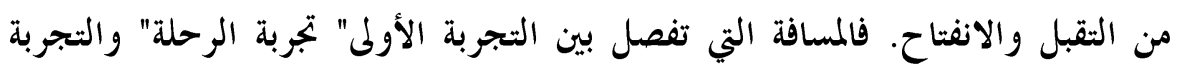

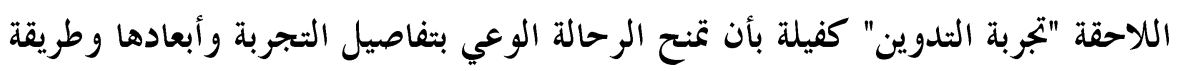
تعامله معها.

وفي نص ابن فضلان نفترض أن الكاتب مدفوع لتدوين رحلته بطلب رسمي من

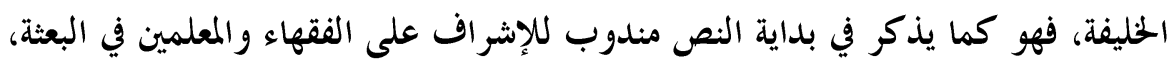

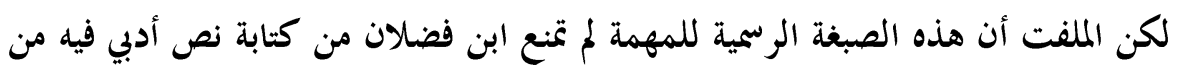

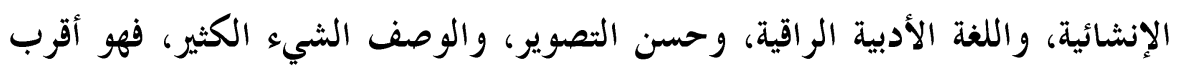

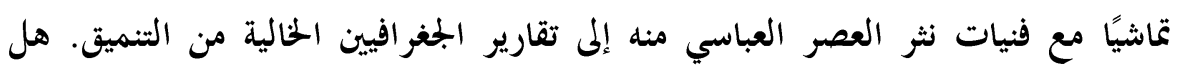

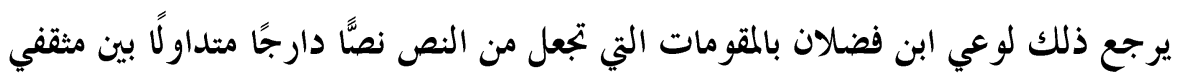

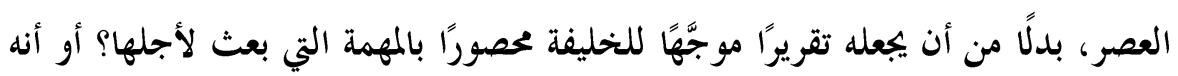

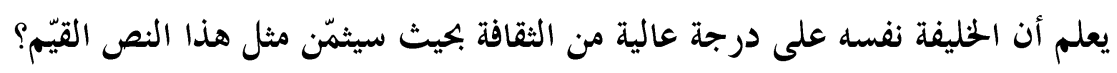

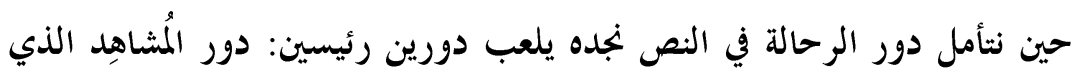

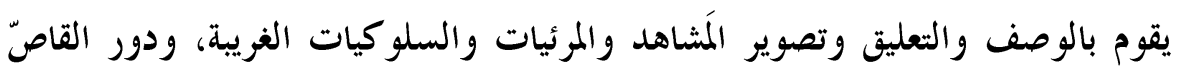

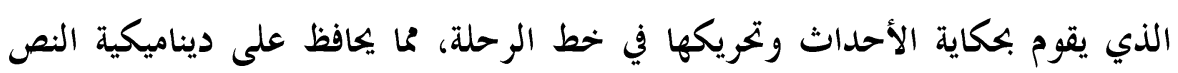

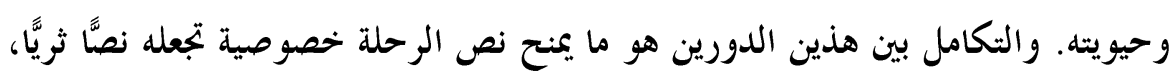


ممتعقا، قريبًا من المتلقي العادي الذي يبحث عن المعلومة الغريبة والمغامرة الشيقة. والوعي

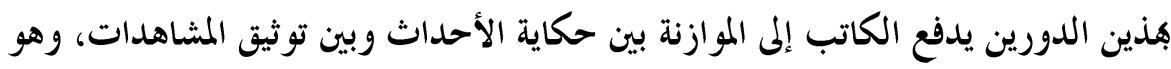

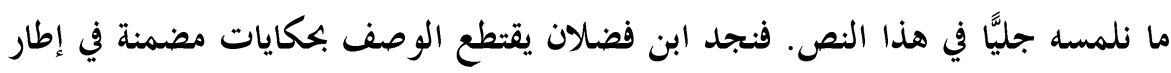

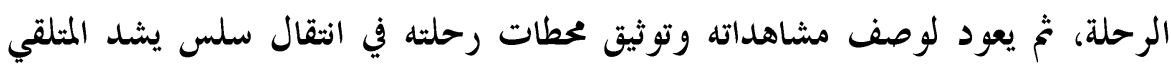
ويمتعه.

والقارئ لرحلة ابن فضلان لا يخفى عليه التزام الرحلة بتقاليد معينة درج الالتزام ها فيما سبق من نصوص الرحلة، كالافتتاح، والتسمية (عنوان الرحلة)، و هدف الرحلة،

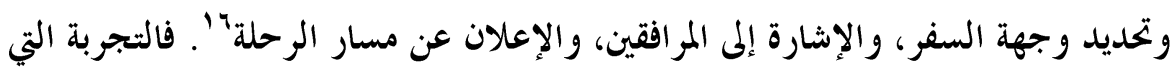

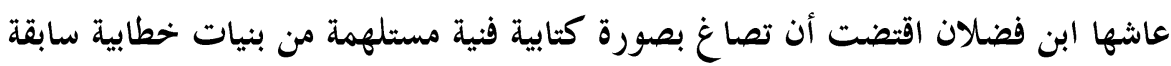
لتجربة الرحلة، ونصوص عديدة مختزنة في خلفية الكاتب. وما كان لمذه التجربة أن تخرج

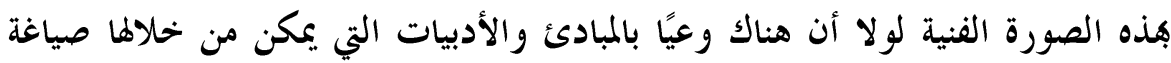

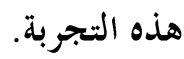

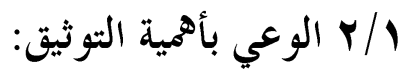

يبدي ابن فضلان اهتمامًا مميزًا بتوثيق تفاصيل الرحلة، فنراه يحدد تاريخ بلوغه كل

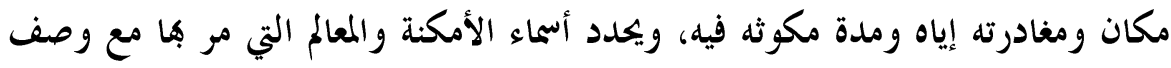
بسيط لها، ويحدد القبائل التي تقطن تلك الأمكنة وأسماء ملو كها، والعملة التي تستخدمهاء أحيانًا. فما الذي يدفع ابن فضلان لهذا التوثيق الدقيق للرحلة؟ تضفي المعلومات الدقيقة التي يوردها ابن فضلان حول أزمنة الرحلة وخط سيرها صبغة علمية على النص، وتمنح مزيدًا من المصداقية والوضوح. إفها تنطلق من رؤية واعية

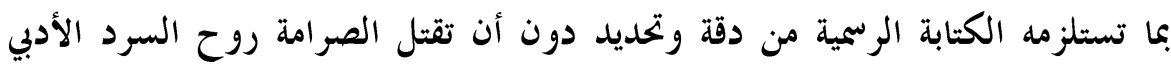
الممتع، بل جعلها الكاتب تنساب ضمنه معبرة عن رغبة حقيقية من الرحالة في تخليد

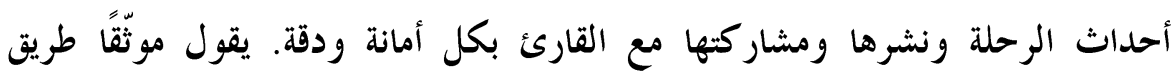
الرحلة: " فرحلنا من مدينة السلام يوم الحميس لإحدى عشرة ليلة خلت من صفر سنة 
تسع وثلاثمئة، فأقمنا بالنهروان يومًا واحدًا، ورحلنا مجدّين حتى وافينا الدسكرة فأقمنا بها

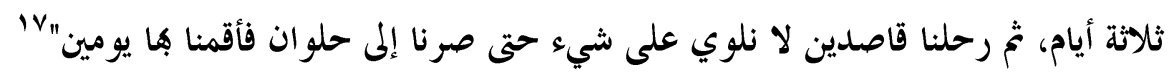
نتيجة لهذا الوعي بالتوثيق الدقيق والاهتمام بتدوين التفاصيل التي ربما بدت في

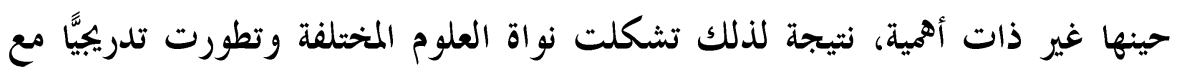

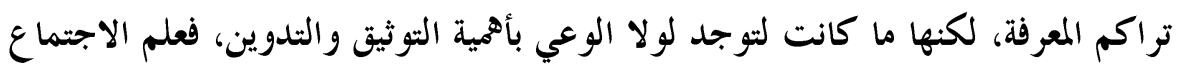

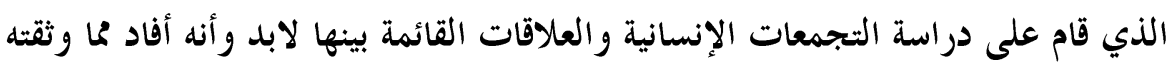

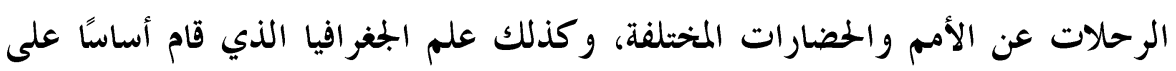

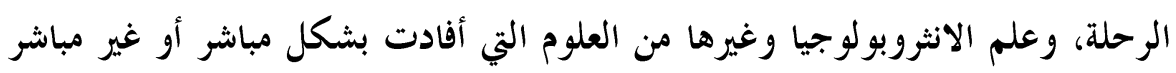

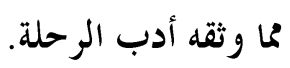
ا / السرد و الوعي بالمتلقي: 1/ 1/ البنية الخطابية الوصفية وقصد التأثير:

يحضر المتلقي في سرد ابن فضلان بكونه متابعا لأحداث الرحلة من جهة، وبكونه متلقيَّا لعمل أدبي من جهة أخرى. ويراعي ابن فضلان إشباع رغبة المتلقي على المستو يين.

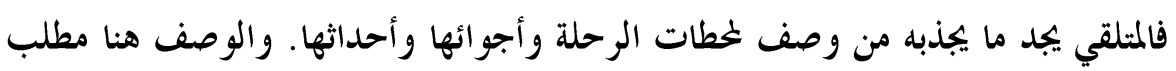

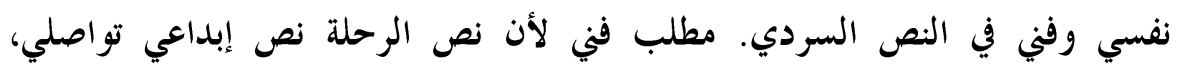

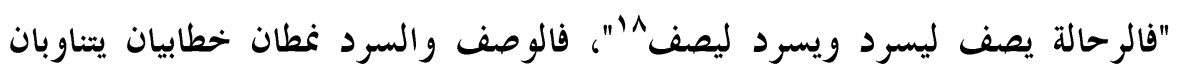

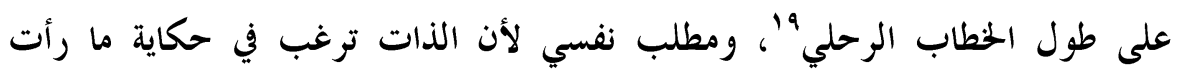

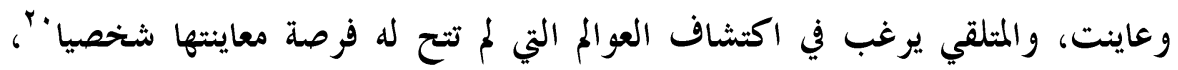

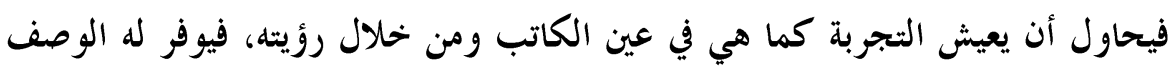

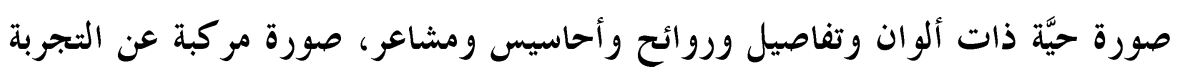
يصعب ترجتها دون لغة وصفية كثيفة.

لنتأمل كثافة اللغة التي يستخدمها لوصف القبائل الروسية حين يقول: "وهم أقذر خلق الله لا يستنجون من غائط ولا بول، ولا يغتسلون من جنابة ولا يغسلون أيديهم من لن لئل 
الطعام، بل هم كالحمير الضالة يجيئون من بلدهم فيرسون سفتهم بإتل وهو فر كبير،

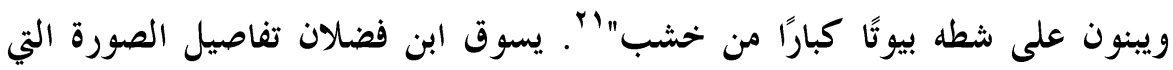
يريد أن ينقلها عن تلك القبائل، ولا يتورع عن تشبيههم بالحمير الضالة ليوسع أبعاد

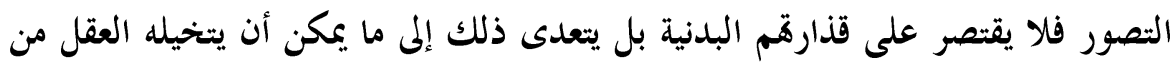
صفات الممجية والوحشية والحيوانية.

ويقول في وصفهم أيضا:" ولا بد لمم في كل يوم من غسل وجوههم ورؤوسهم

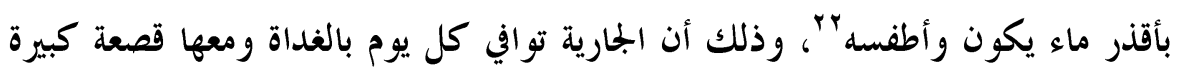

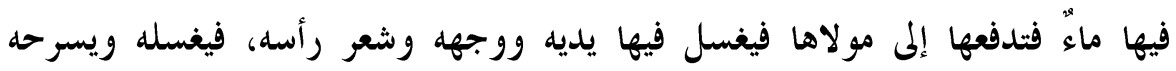

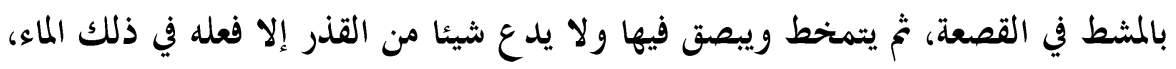

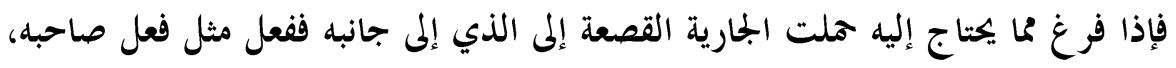
ولا تزال ترفعها من واحد إلى واحد حتى تديوها على جميع من في البيت، وكل والى واحدٍ

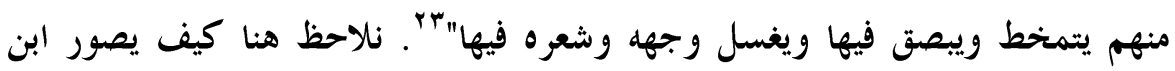

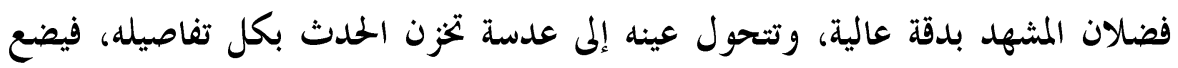
القارئ موضع المتفرج المتابع دون أن يفوته شيء من المشهد، وفي الوقت ذائه ذاته يفتح له له

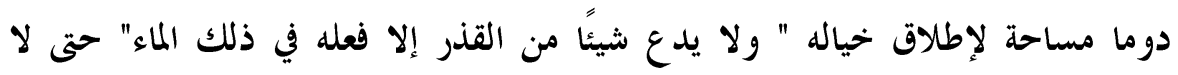

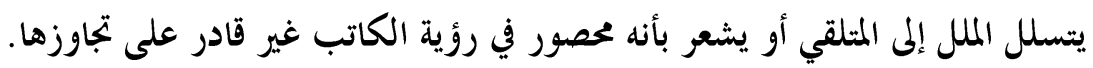
وبهذه اللغة الوصفية الخملة بالصور والمشاهد والانفعالات يستطيع ابن فضلان أن

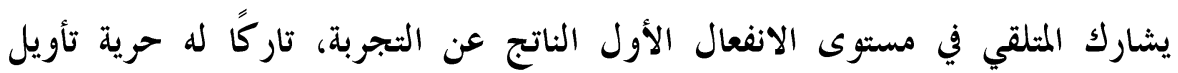
الصورة الكلية للقوم الذين يصفهم .

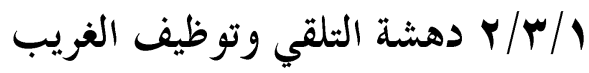
يصطدم الرحالة في رحلته بكثير من العجائب التي تثير الدهشة وتدير الرؤوس،

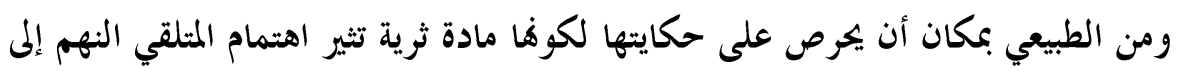

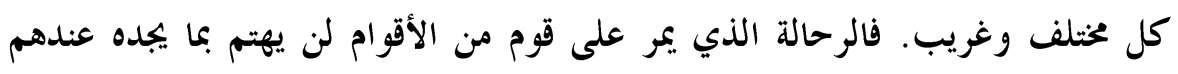

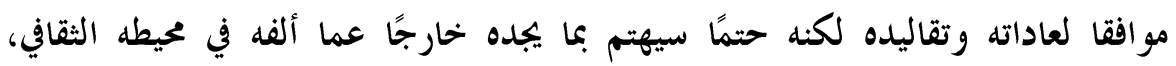


وسيهتم بتدوينه لأنه يكتب نصَّا لمتلقٍ سيشار كه الدهشة والانفعال. هذا فيما يتعلق بسرد الغرائب بصفة عامة، لكننا هنا بصدد الكلام عن توظيف الغريب والعجيب بشئ بشكل

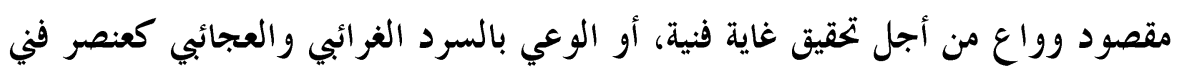
له قيمته وتأثيره على المتلقي.

يستخدم ابن فضلان تقنية التصوير ليخرج بعض المشاهد الحارجة عن المألوف بطريقة فنية، تطبع في ذهن المتلقي صورة مميزة بغرابتها، تسهل على المخيلة استحضار

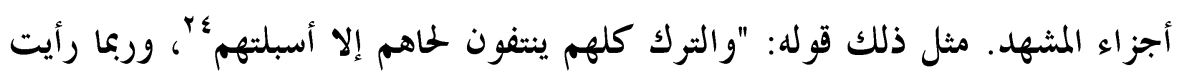

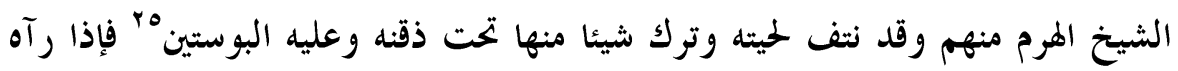

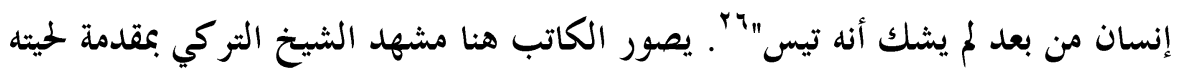

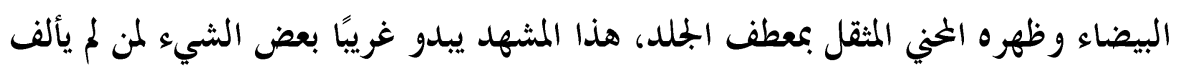
هذه الصورة، لكن الأكثر غرابة هي صورة التيس التي يبتكرها ابن فضلان ويلصقها بكل بله

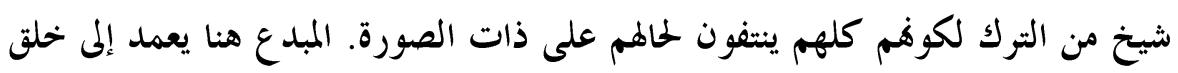

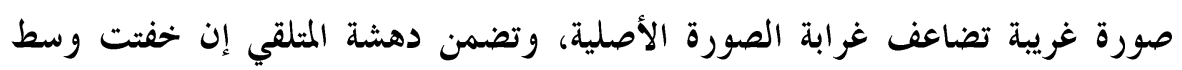
سرد مليء بالغر ائب.

من باب الغريب أيضا يسرد ابن فضلان مغامرته مع الحيَّات في بلاد الصقالبة

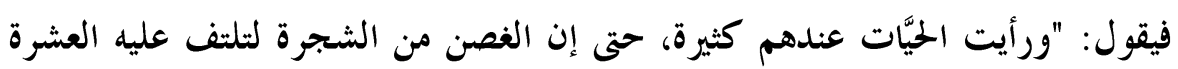

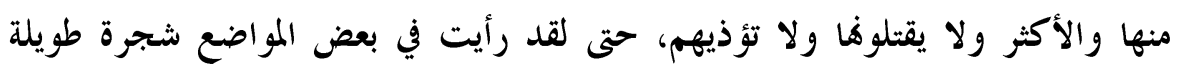

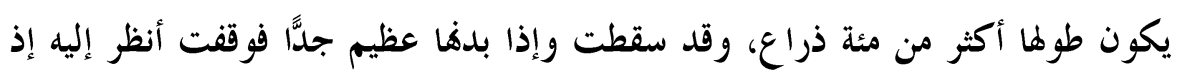
تحرك، فراعني ذلك، وتأملته فإذا عليه حية قريبة منه في الغلظ والطول فلماع ونما رأتني سقطت

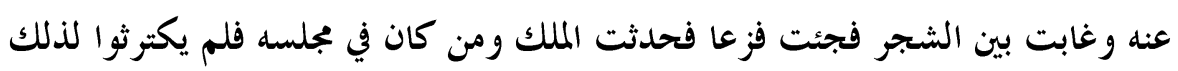
، وقال: لاتجزع فليس تؤذيك"

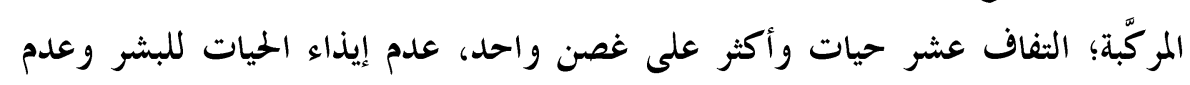

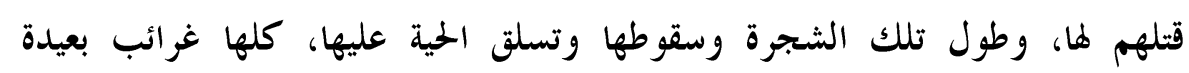

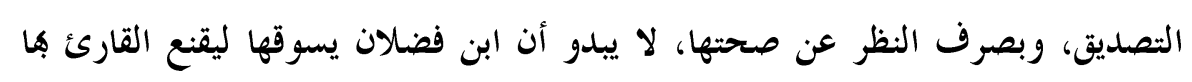


بقدر ما يعمد من خلالها إلى إشباع رغبته النهمة لتلقي المادة الغرائبية في ظل ثقافة صار

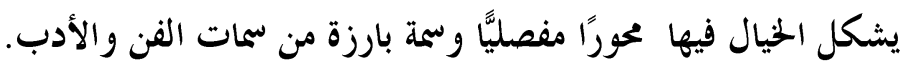
أما بالنسبة للسرد العجائبي يفاجئ ابن فضلان المثلقي بحكاية ملحمية عن معر كة

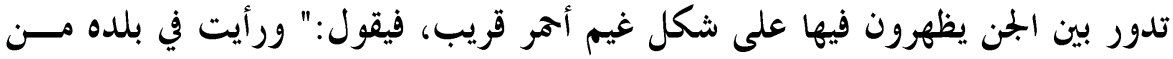

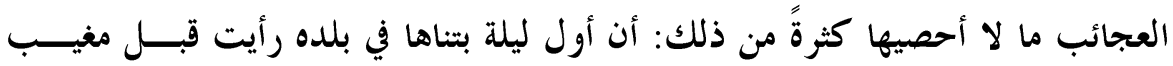

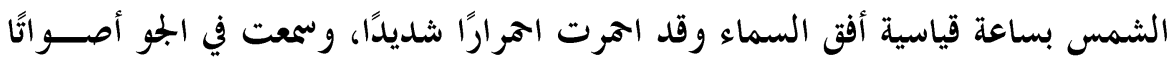

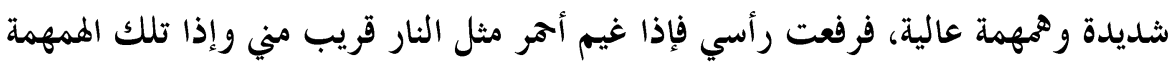

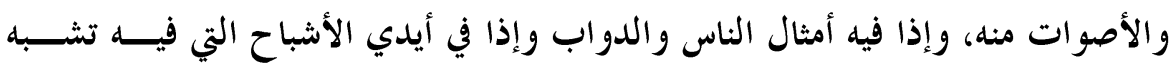

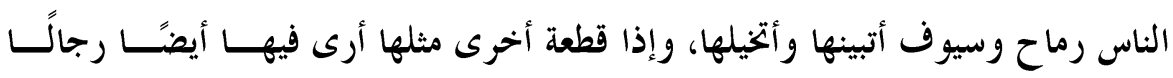
ودواب وسلاحًا، فأقبلت هذه القطعة تحمل على هذه كما تحمل الكتيبة على الكتيبــة. ففزعنا من ذلك وأقلنا على التضرع والدعاء وهم يضحكون منا ويتعجبون من فعلنا. قال: و وكنا ننظر إلى القطعة تحمل على القطعة فتختلطان ميعاً ساعة ثم تفترقــان،

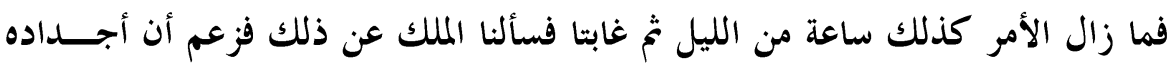

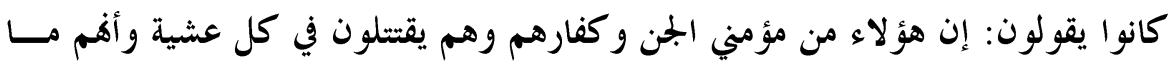

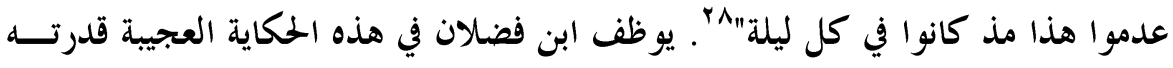
على الوصف بلغة مكثفة تنقل القارئ إلى عالم مشحون بالرهبة والحوف، فالنفاذ إلى عالم

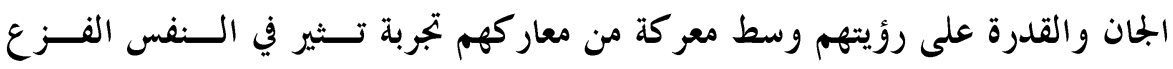

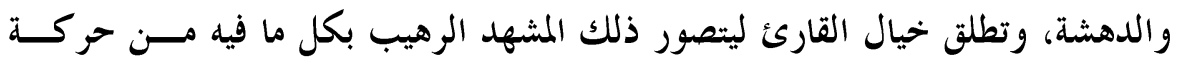
وصوت وكائنات. وبعد أن يعيش القارئ مع ابن فضلان هذه التجربة العجيبة يتفاجئ في

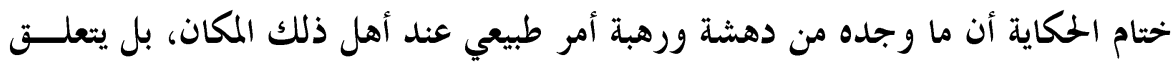

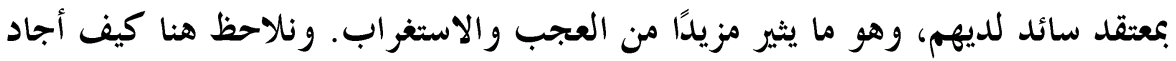

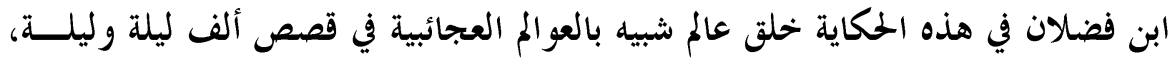

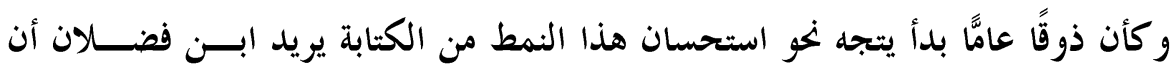
يجاريه. 
ولا يمكننا أن ننهي الحديث عن العجائبية في النص دون التوقف عند قصة يوردها ابن فضلان عن رجل ضخم من قوم يأجوج ومأجوج فيقول: " و كان تكين حدثني أن في

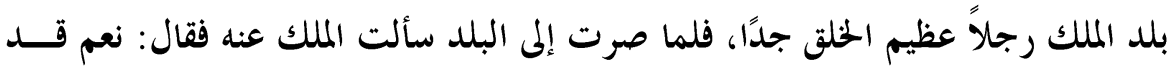

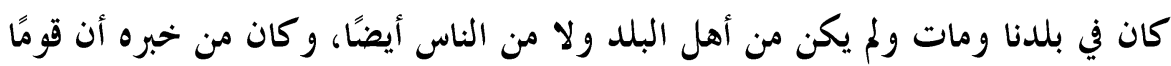

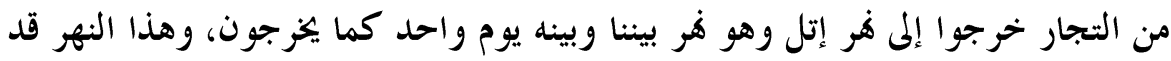

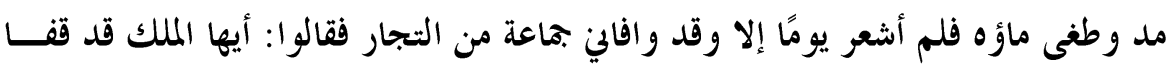

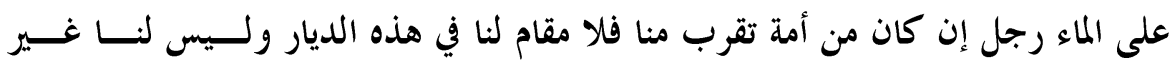
التحويل.

فركبت معهم حتى صرت إلى النهر فإذا أنا بالرجل، وإذا هو بذراعي اثنا عشـــــ

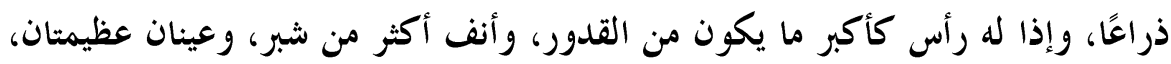

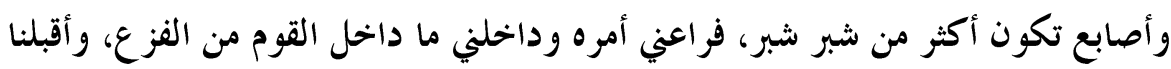

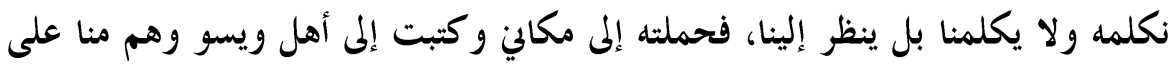

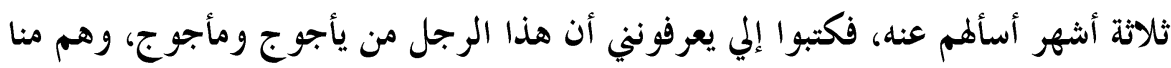

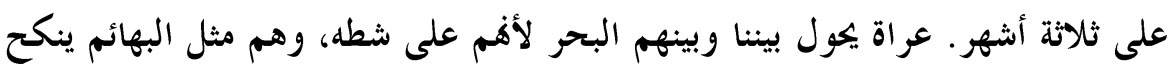

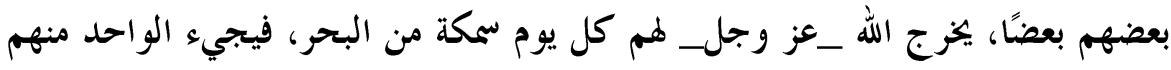

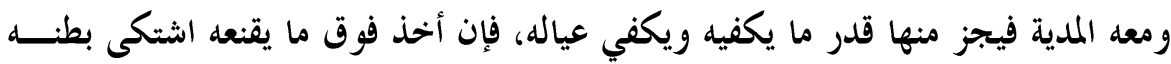

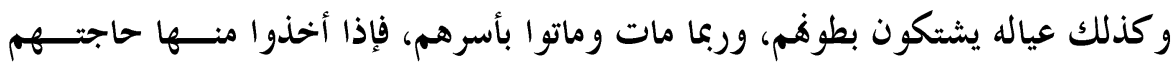
انقلبت ووقعت في البحر، فهم في كل يوم على ذلك.

وبيننا وبينهم البحر من جانب والجبال محيطة بهم من جوانب أخر، والسد أيضًا قد

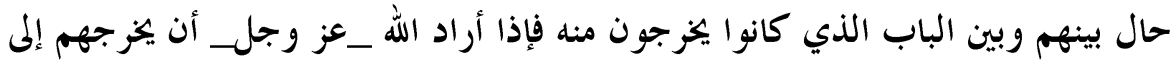
العمارات سبب لهم فتح السد ونضب البحر وانقطع عنهم السمك. قال: فسألته عن الرجل فقال: أقام عندي مدة فلم يكن ينظر إليه صبي إلا مــات

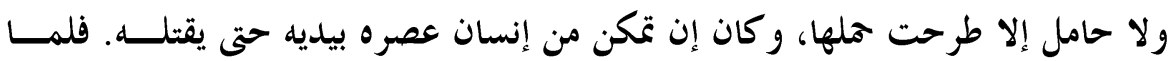

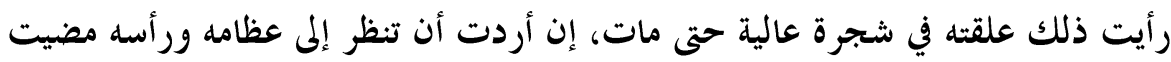


معك حتى تنظر إليها، فقلت: أنا والله أحب ذاك فر كب معي إلى غيضة كبيرة فيها شجر

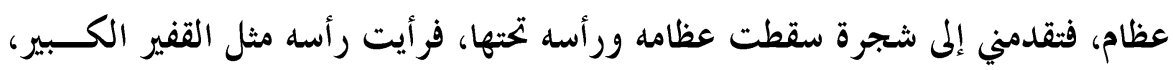

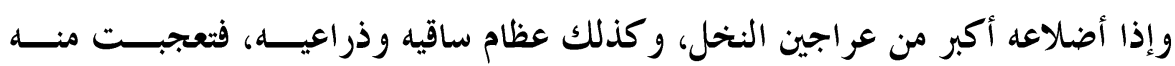

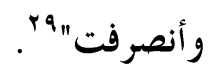

تشكل هذه الحكاية عنصر جذب كبير للمتلقي لكوفا تستند إلى قوم يأجوج ومأجوج الذين ورد ذكرهم في القر آن الكريم، وحيكت حولهم الكثير والكثير من الأخبار

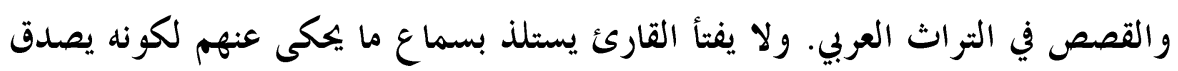

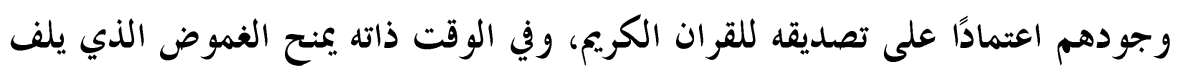

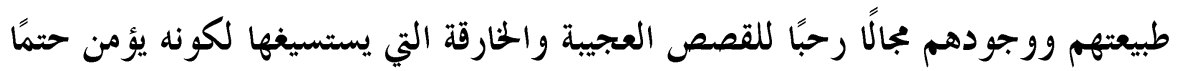

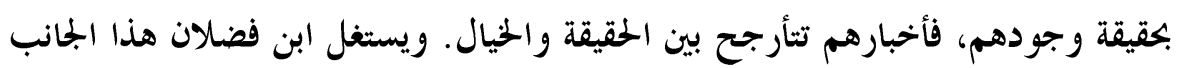

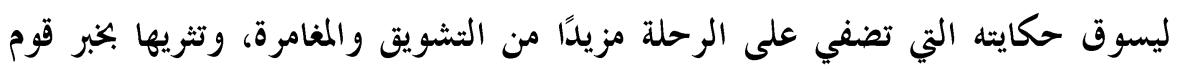
ينتظر القارئ في الثقافة العربية سماع المزيد عنهم. وفي سياق الحديث عن العجائبية والغرائبية في رحلة ابن فضلان يستخدم أندريه

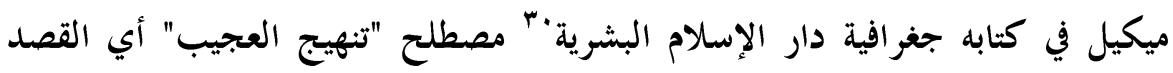

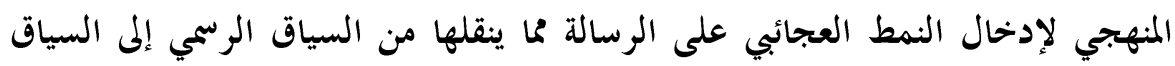

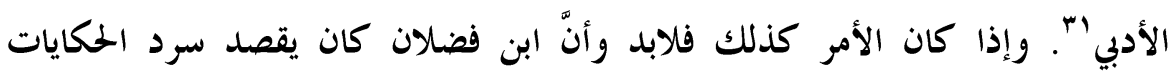
الغرائية والعجائبية وعيًا منه بما تحدثه من فرق في نوعية النص وما لها من أثر على الثلى المتلقي. هذا الوعي الذي نلمسه في حرص ابن فضلان على جذب القارئ لمغامراته والعناية بإنتاج

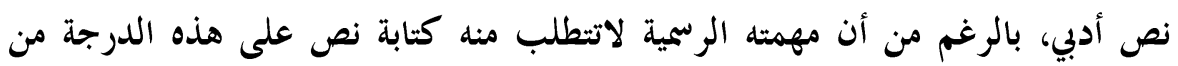

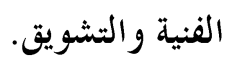

/ / / الوعي بقيمة الذاتية وإظهار خصوصية التجربة:

يحرص ابن فضلان على إشر اك المتلقي بتجر بته الشخصية ومغامرته الفريدة، وبعث

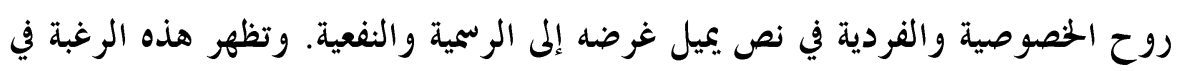
تكريس خصوصية تجربته ومغامرته في عدة ملامح: 
أ/ نجد ابن فضلان ينصّب نفسه بطلًا للحكايات المُضمَّنة في سياق الرحلة، ويجعل

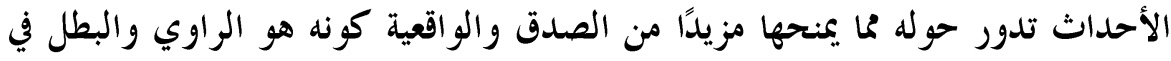
الوقت ذاته، ويعمد إلى جعل القارئ يتابع معه الأحداث بتسلسلها فيعيش دور البطائ البطال

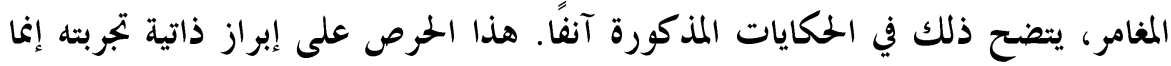

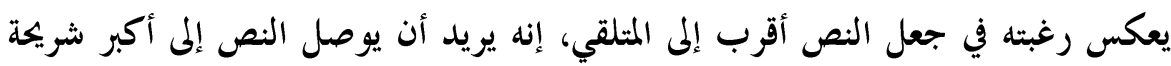

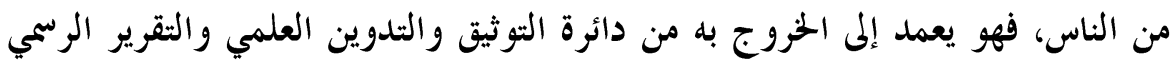

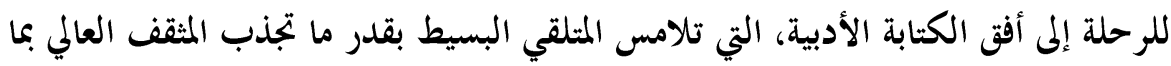

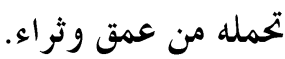

ب/ يعمل ابن فضلان على إظهار مشاعره وانفعلاته في المواقف المختلفة، هذه

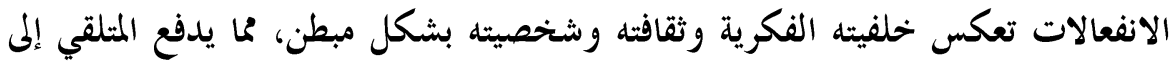
التوقف والتفكير في الموقف وردة فعل ابن فضلان تجاهل، ويمنحه فرصة لإعمال فكره في

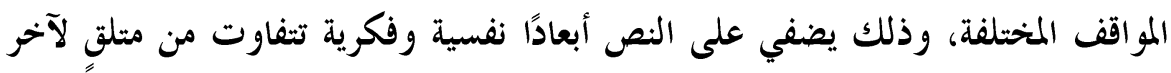

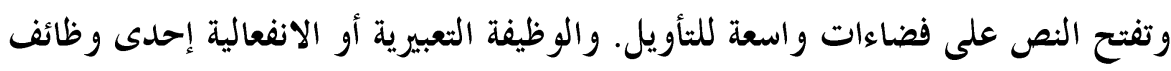

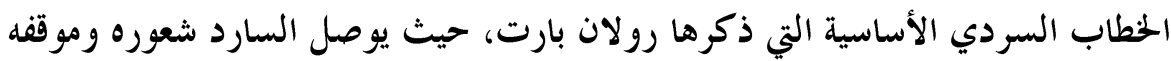

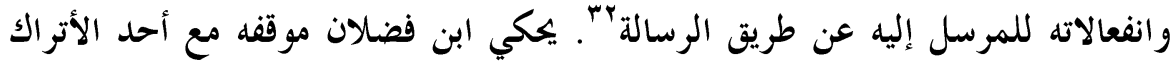

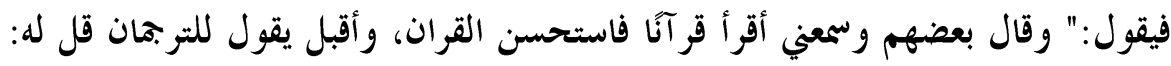

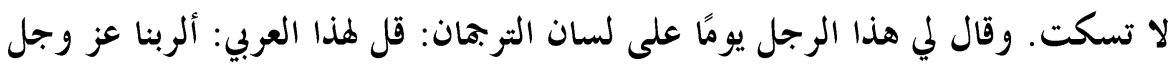

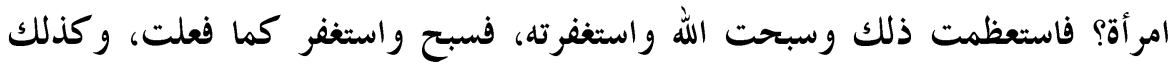

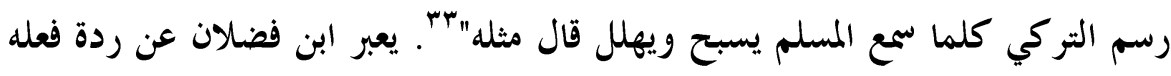

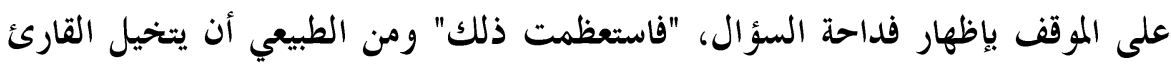
تعابير التعجب والغضب التي أظهرها ابن فضلان وهو رجل الدئل التين الملتزم، ونبرة التسبيح

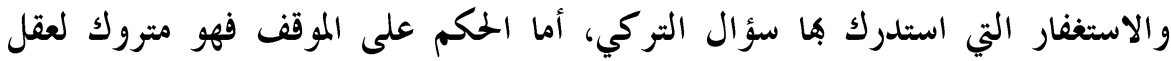

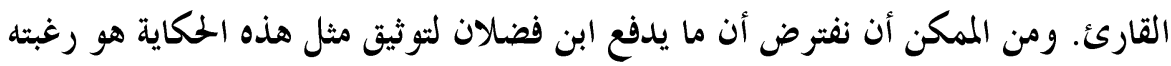

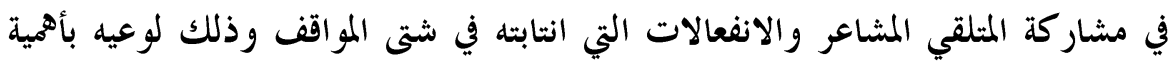
ذلك في تقريب النص للمتلقي وجعله أمتع تناولًا وأكثر جاذبية. 
ج/ يبدي ابن فضلان وجهة نظره في بعض القضايا والمواقف التي تواجهه في

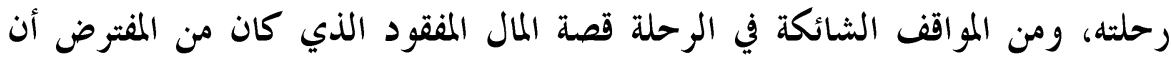

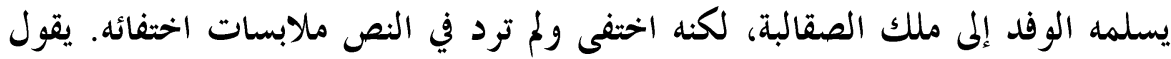

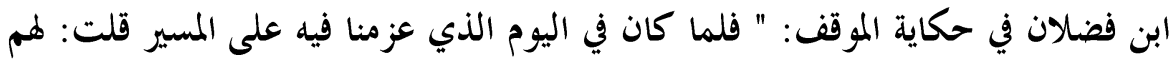

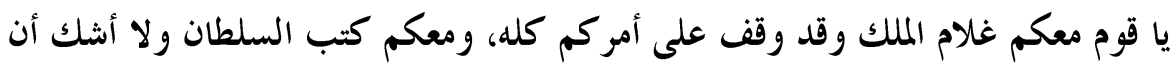

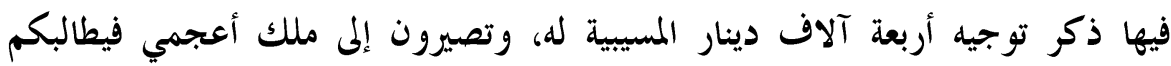

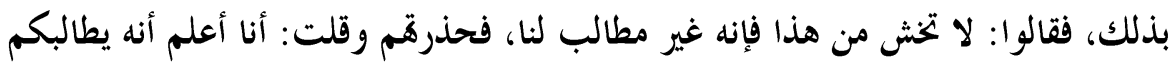

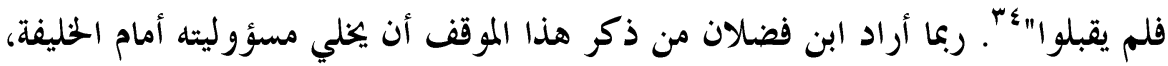

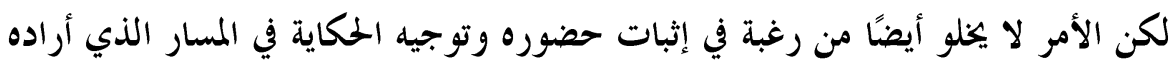

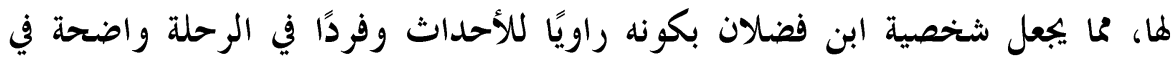

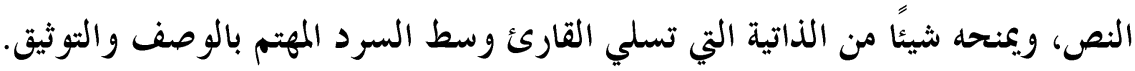

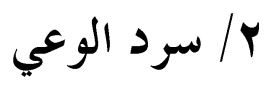

الرحلة فعل يضع الإنسان في مواجهة مع الآخر، هذا الآخر المختلف في ثقافته

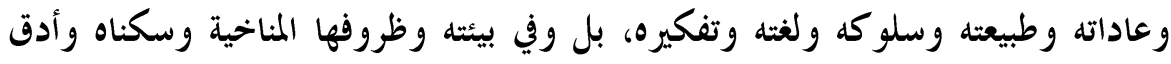

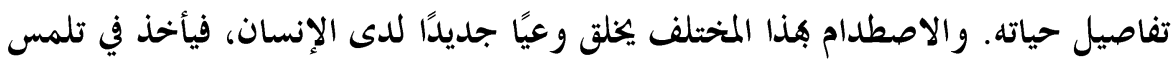

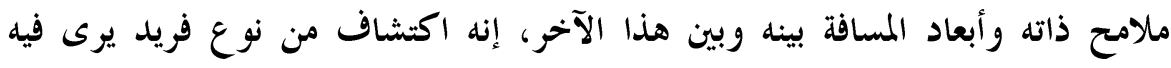

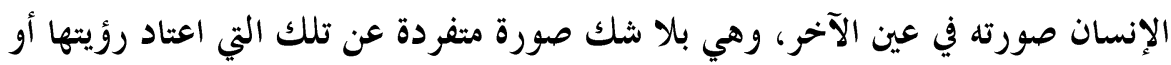

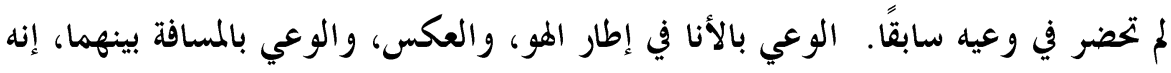

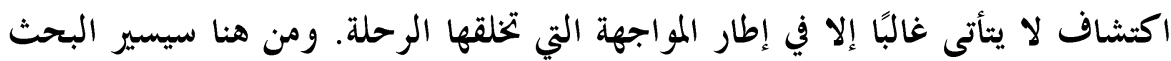
في هذا الجلال في منحيين أولما منحى استبصار الذات، وثانيهما منحى استبصار الآخر. ا 1/ استبصار الذات في حضور الآخر:

يبدأ ابن فضلان رحلته وأمامه رؤية واضحة للمهمَّة المو كلة إليه، فهو منسـدوب

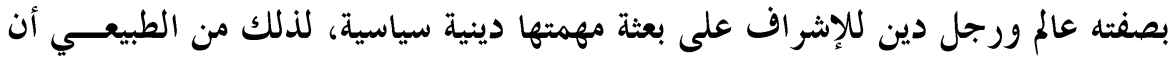

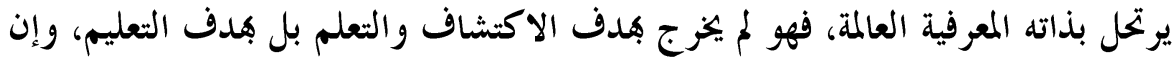


كان الارتحال يقود بطبيعته إلى الاكتشاف. وسنحاول هنا أن نتلمس تجليات هذه الذات

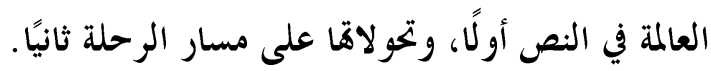
r// / الارتحال المعرفي وحضور الذات العليا: بعد أن يعلن ابن فضلان وظيفته في البعثة يسير في طريق الرحلة كفرد في الجموعة،

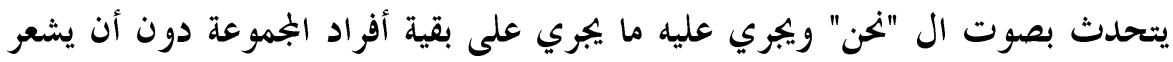

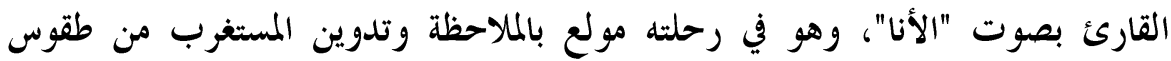
وعادات ومعتقدات الأقوام التي يقابلها، دون أدلن محاولة منه للتقويم أو النصح وفت بلى رؤيته

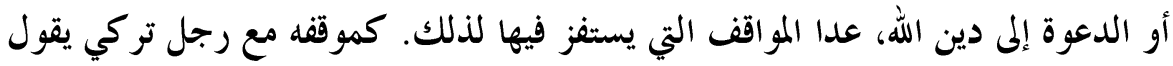

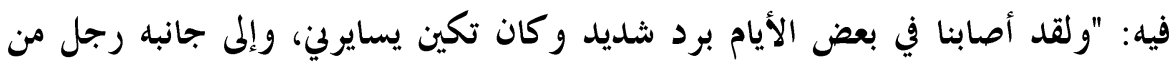
الأتراك يكلمه بالتر كية فضحك تكين، وقال: إن هذا التركي يقول لك: أي شيء يريد

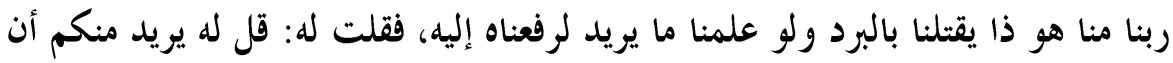

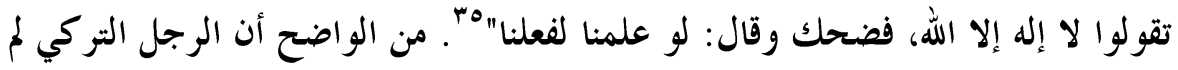

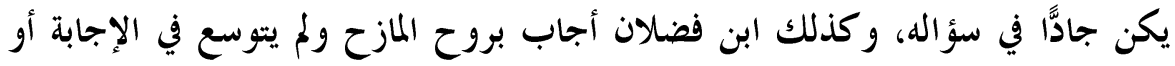

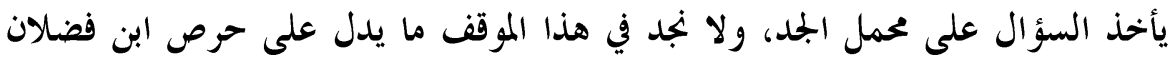
على الدعوة أو اتخاذه موقف المعلم الحريص على التبليغ. وهناك أيضًا الموقف المذكور سابقًا حين سأله التركي "ألربنا عزوجل امرأة؟"

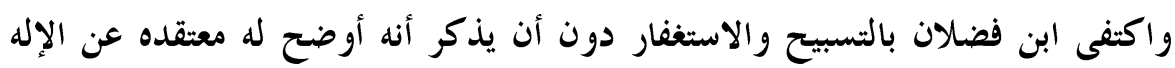
والتوحيد أو أنه استغل الفرصة لدعوته للإسلام القويم. وهنا موقف آخر يظهر فيه ابن فضلان غير آبه بالتعليم والمبادرة، مكتفٍٍ بردود الفعل التي يمكن أن تفسَّ على أذها سلبية.

لكن هذه الصورة تتخذ منحى آخر بعد وصول البعثة إلى وجهتها المقصودة، فما إن يصل ابن فضلان إلى بلاد الصقالبة، حتى تظهر عنده روح التميز وصوت "الأنا" العالمة المتفوقة ذات الثقافة الأعلى، ويتحدث بلهجة الموجّه الذي يسعى إلى التعليم والدعوة،

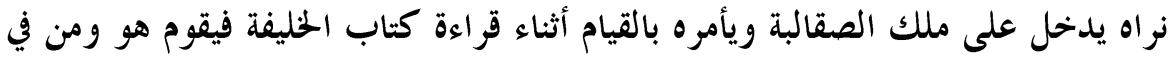


الجلس، ثم يأمره برد السلام على الحليفة فيرد، ثم يأمره بالجلوس عند قراءة كتاب الوزير

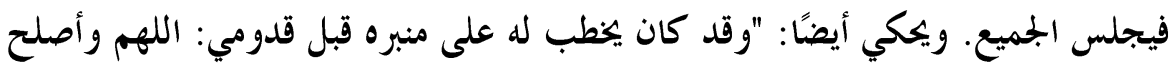

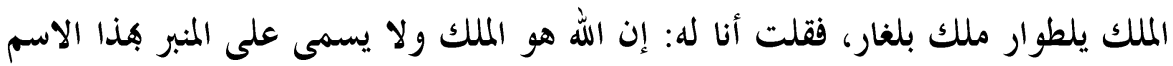
غيره _جل وعز_ وهذا مولاك أمير المؤمنين قد رضي لنفسه أن يقال على منابره في

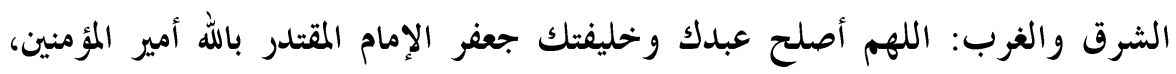

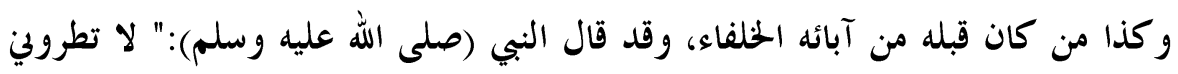

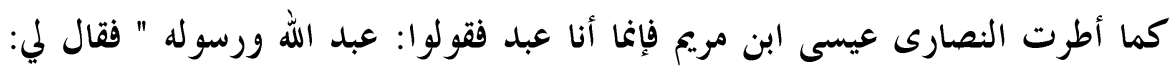

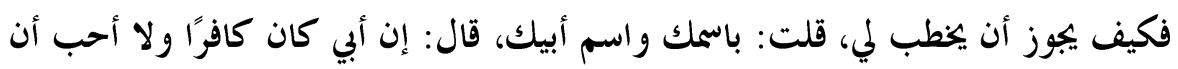

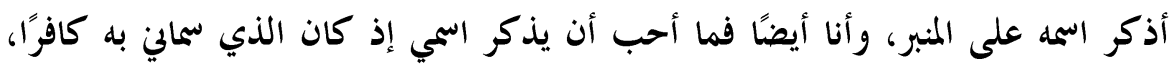

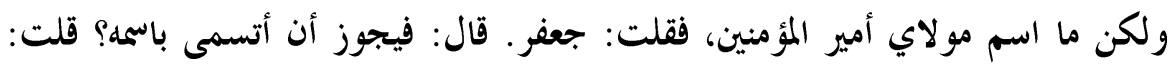

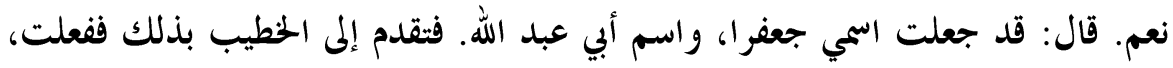

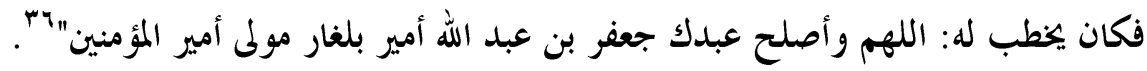
ويحكي ابن فضلان أيضًا: "و كان مؤذنه يثني الإقامة إذا أذَّن، فقلت له: إن مولاك أميز المؤمنين يفرد في داره الإقامة، فقال للمؤذن: اقبل ما يقوله لك ولك ولا تخال تحالفه. فأقام المؤذن على ذلك أيامًا، وهو يسألني عن المال ويناظربي فيه، وأنا أويسه منه وأحتج فيه، لهنه

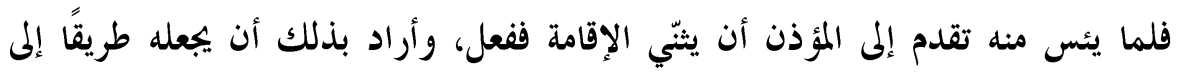

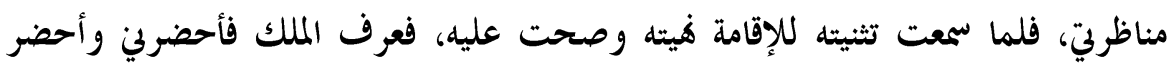

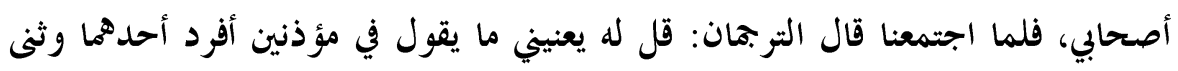

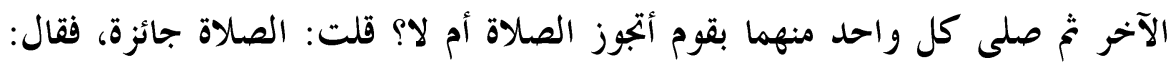

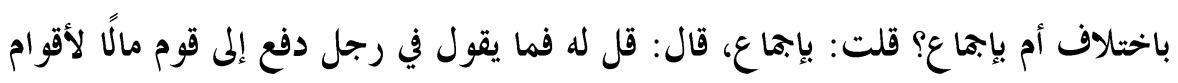

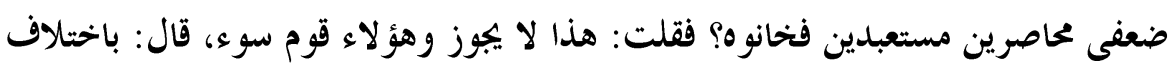

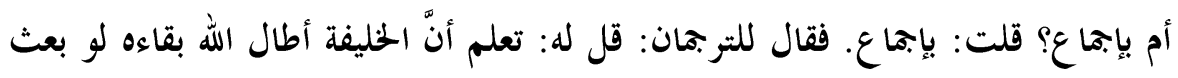

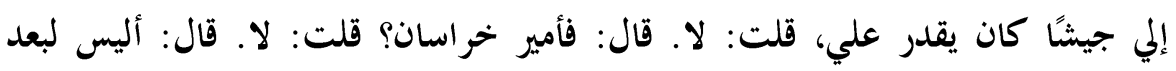

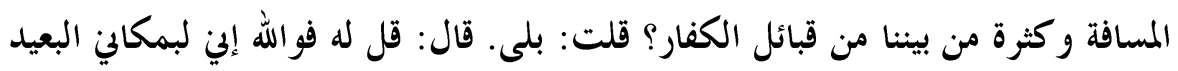

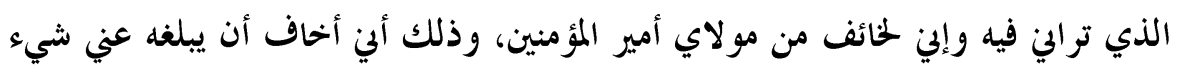


يكرهه فيدعو علي فأهلك بككاني، وهو في مملكته وبيني وبينه البلدان الشاسعة، وأنتم

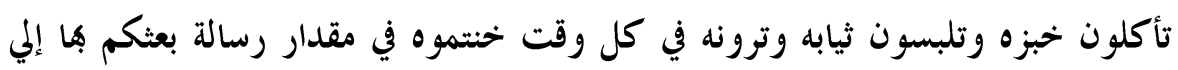

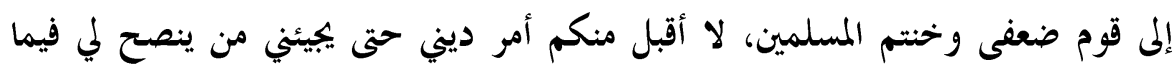

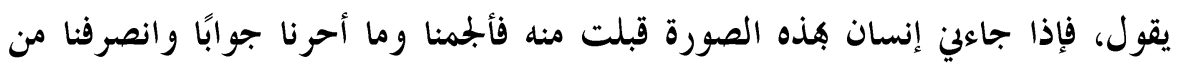

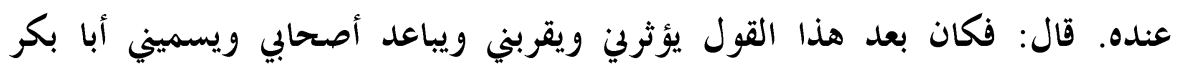

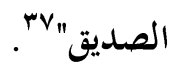

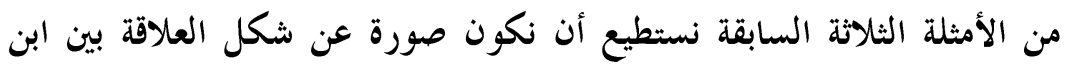

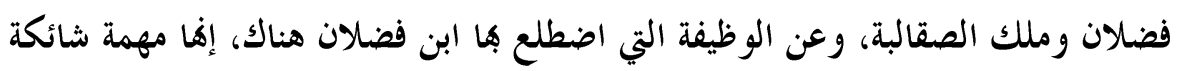

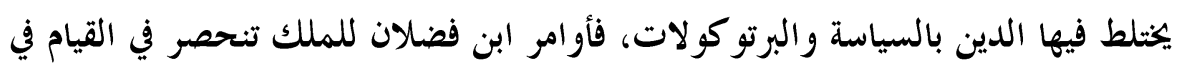
حضرة قراءة كتاب الحليفة، وفي عدم استخدام لفظة الملك في الدعاء، وإفراد الإقامة،

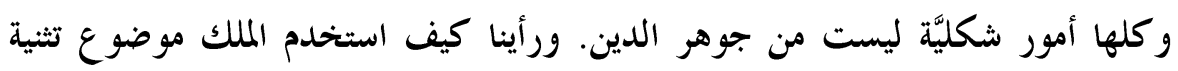

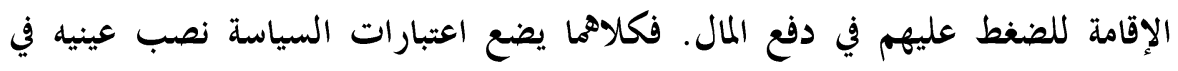

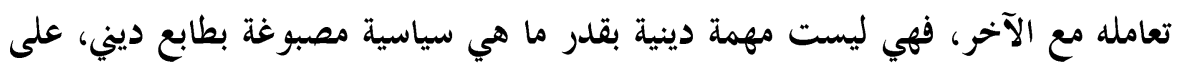

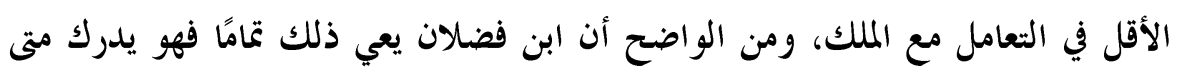
يفرض قوته ومتى يتر انحى، ويدرك حدود مهمته ومسؤولياته.

ويختلف الأمر في تعامله مع الناس هناك فهو يسعد بالدعوة وتعليم الناس القرآن

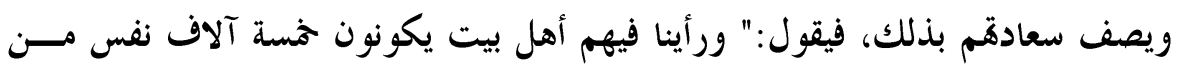

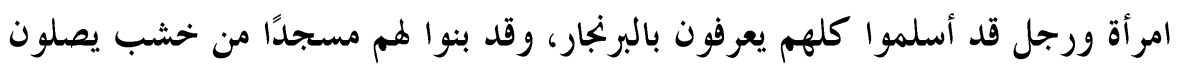

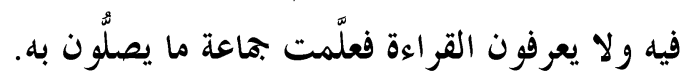

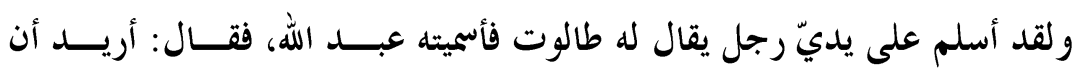

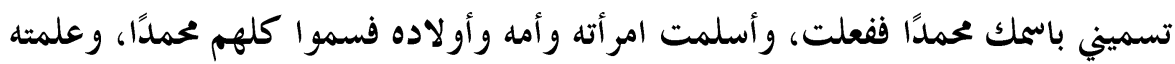

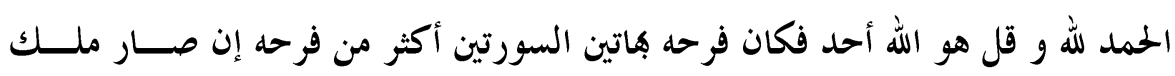

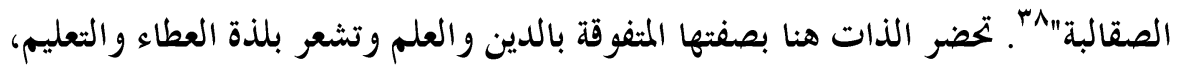


ويشي السرد بنشوة النجاح والإنجاز، وبالرغم من أن ابن فضلان لا يمكي تفاصيل دعوته للناس إلا أن إسلام رجل على يديه يدل على محاو لاته.

$$
\text { r/ / / r/ تحو لات الذات على مسار الرحلة: }
$$

تحتم الأحداث التي يو اجهها الرحالة في طريق رحلته وظائف مختلفـــة يتقمصــها ويؤديها بعد أن تجره إليها ججريات الأمور، ويجد نفسه أمام أدوار يلعبها ويختبر نفسه فيها دون سابق تجربة. فابن فضلان يخرج من بغداد وفي مخيلته صورة عن ذاته وهو العالم الفقيه الذي يريد أن يدعو الناس إلى دين الله، ويجتهد أن يؤدي مهمته التي تقتضي كتابة تقرير

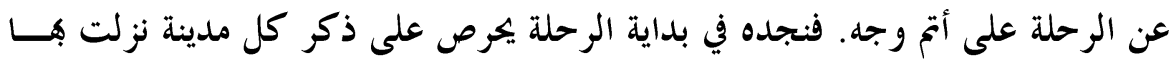

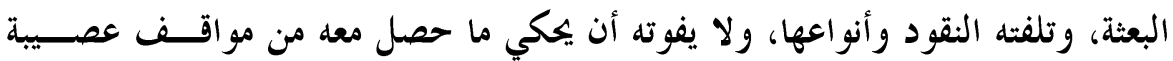
وشائكة.

ثم تقوده الرحلة إلى قبيلة الغزية وهي قبيلة من الأتر اك ويبدأ في ملاحظة سلو كهم

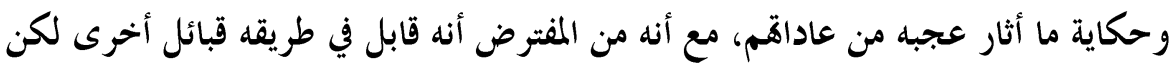

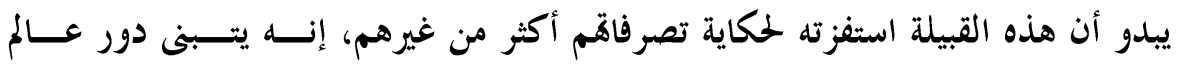

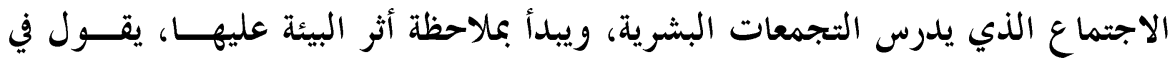

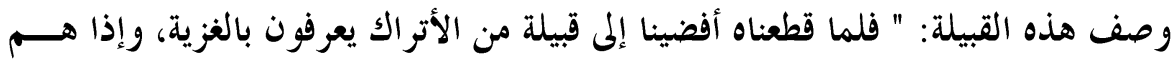
بادية لهم بيوت شعر يحلون ويرتحلون ترى منهم الأبيات في كل مكان ومثلها في مكــان

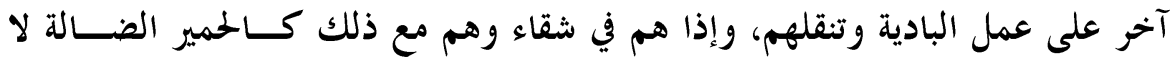

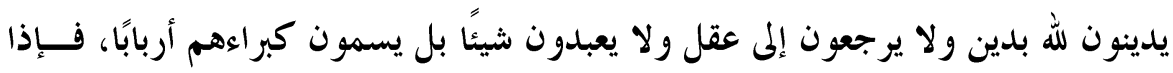

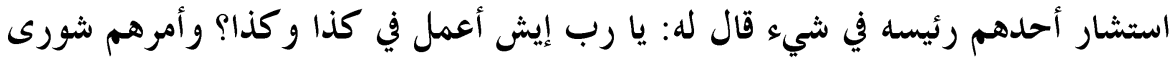

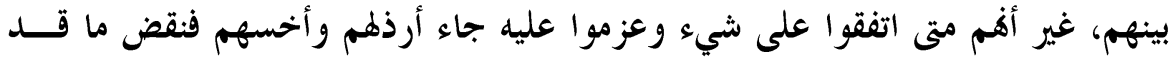

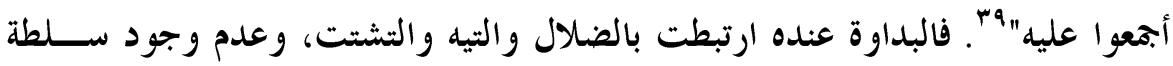

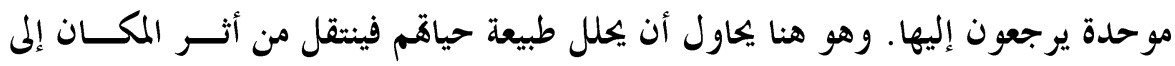

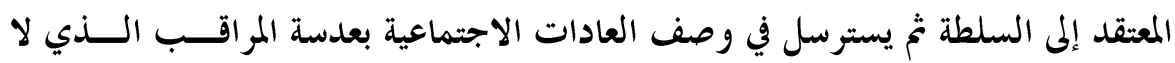

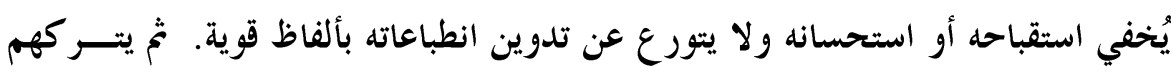


ويكمل السير في رحلته وهو مأخوذ بعادات الأقوام وطبائعهم، مفتون بالمغامرة والتأمــل

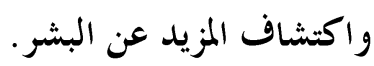

ويمر بمو اقف عصيبة توضع فيها حياته على الخكك ولا يكون أمامه إلا الصبر وضبط

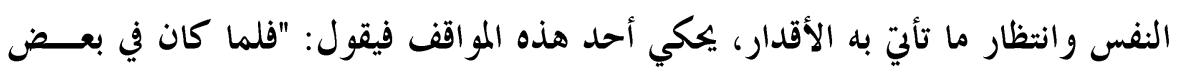

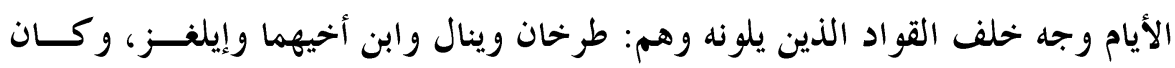

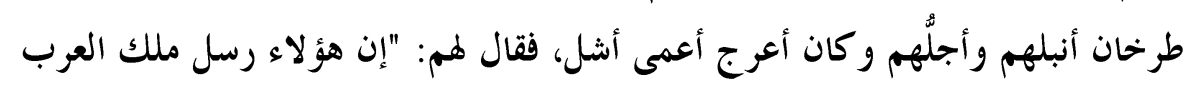

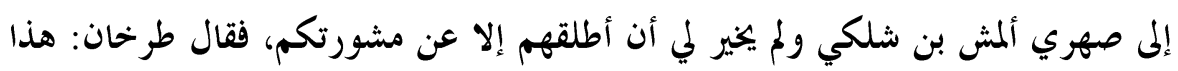

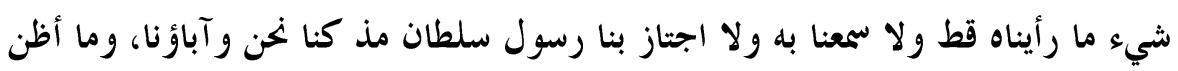

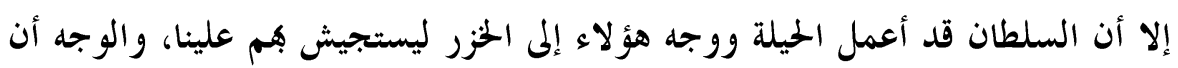

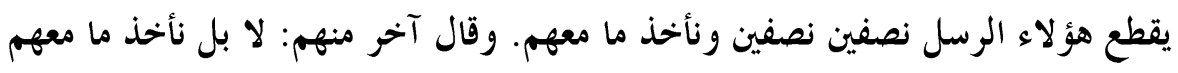

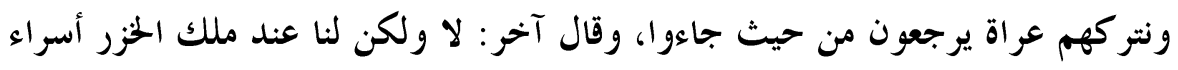

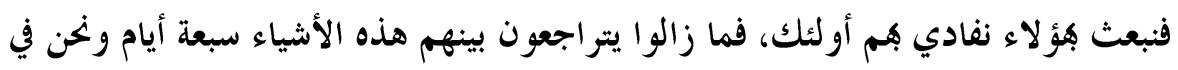

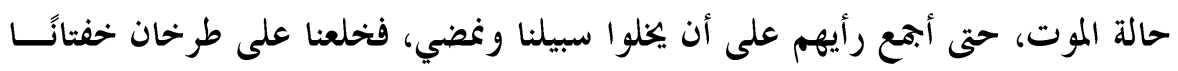

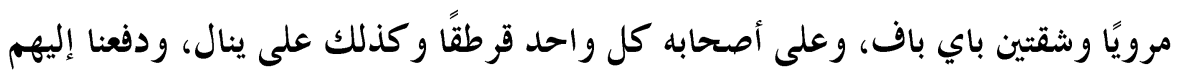

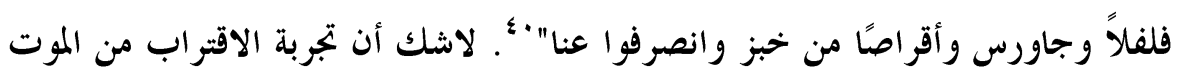

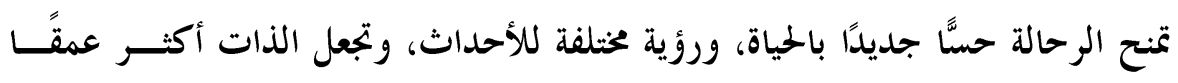

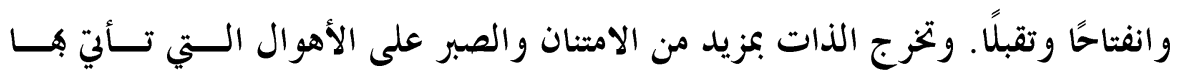

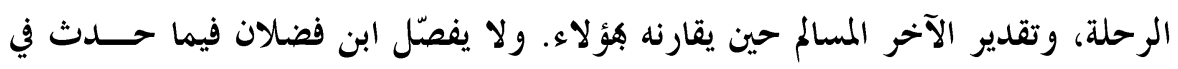

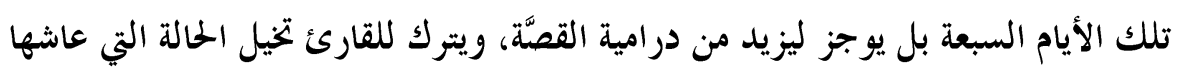

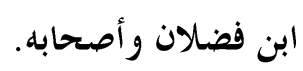

ويدخل ابن فضلان على الملوك فينظر إليهم بعين السياسي الذي يجيد فرض نفسه

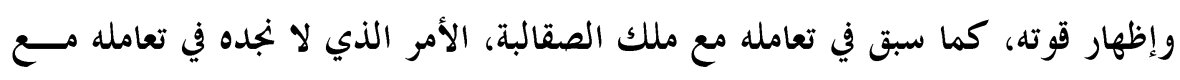

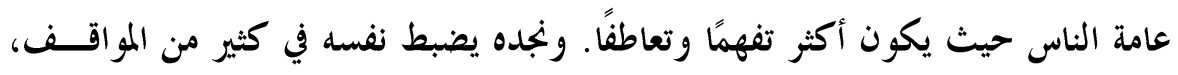

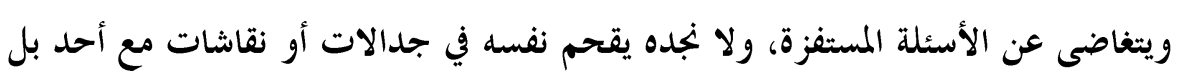

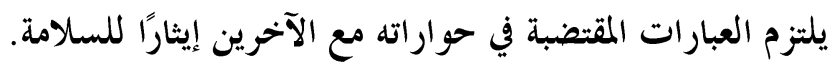


وهكذا يضطلع ابن فضلان في رحلته بعدة وظائف، وتملي التحولات في طريسـق

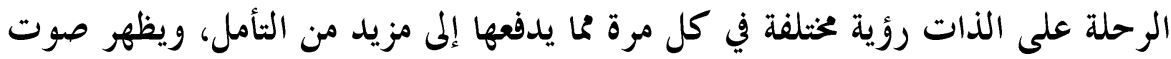

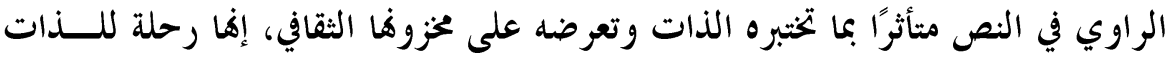
وسط عالم مختلف تمتحن فيه قدرقا على الفهم والوعي بتقدير الأمور والاستفادة من هذه

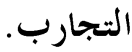

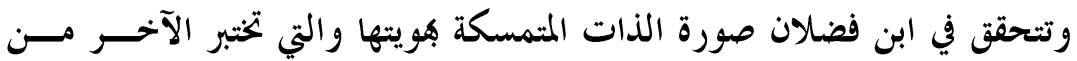

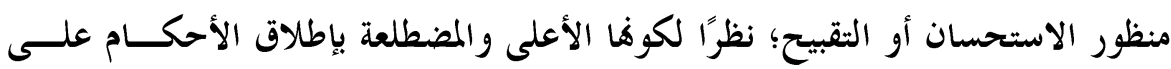

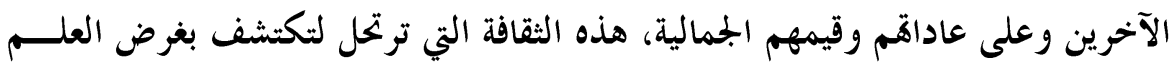

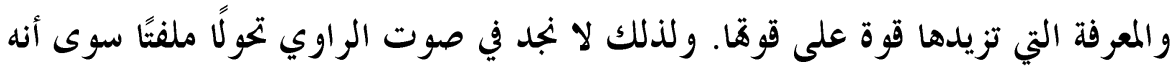

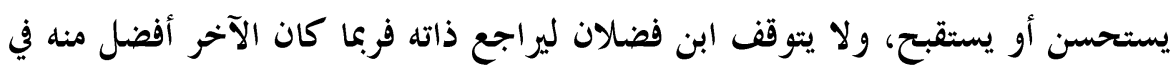

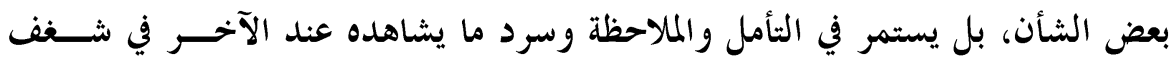

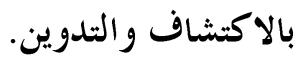
r/r استبصار الآخر في مر آة الذات:

يحمل الرحالة معه ثقافته الأم وفضاءه الأليف ويستخدمهما لتفسير الآخر بكسل اختلافه وغرابته. والإنسان يرى الآخر من منظور وعيه، ويقيّمه بناء على خلفيته وثقافتهنه

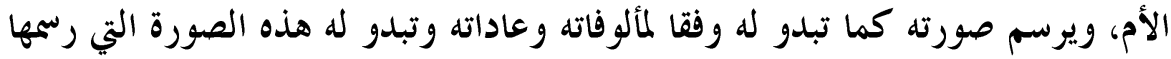

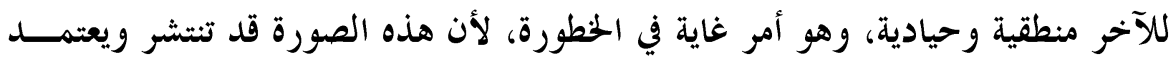

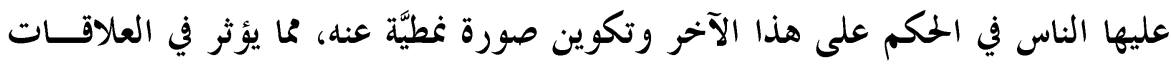
السياسية والاجتماعية وشتى قنوات التواصل بالآخرين.

يهتم ابن فضلان بمعتقدات القبيلة التي ينزل بينها وما تؤمن به، فيذكر عن قبيلـــــ

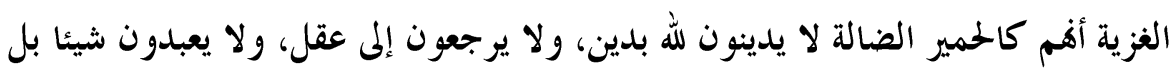

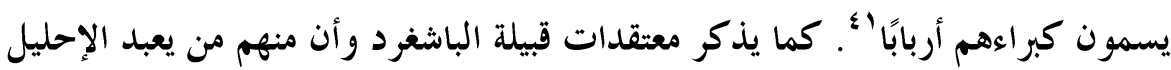

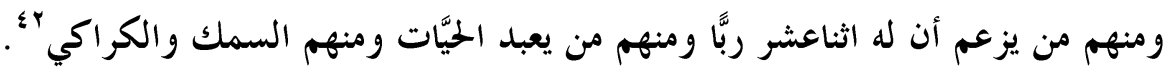

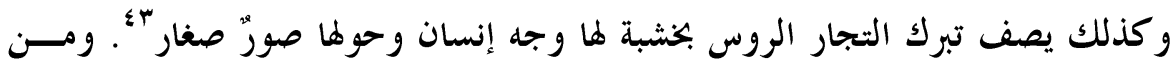




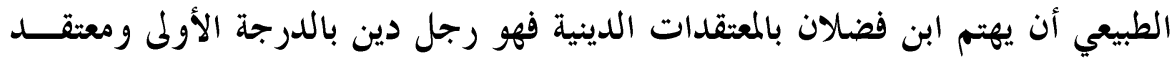

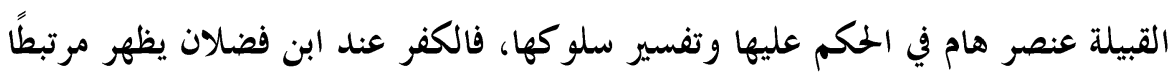
بالتو حش والقذارة و الممجية.

ويلتفت ابن فضلان لشكل السلطة في القبيلة، ففي قبيلة الغزية يقول: "أمــرهم

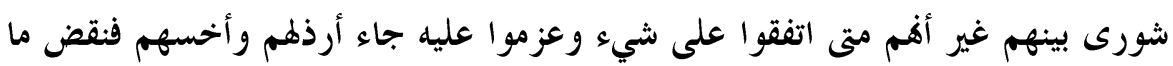

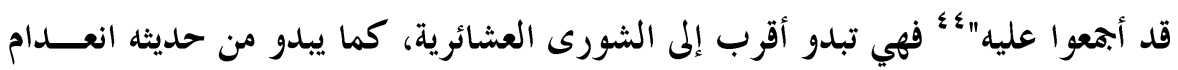

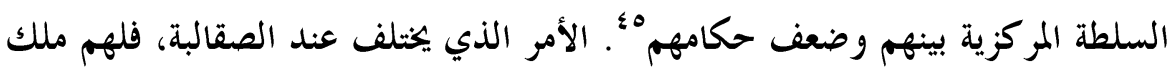

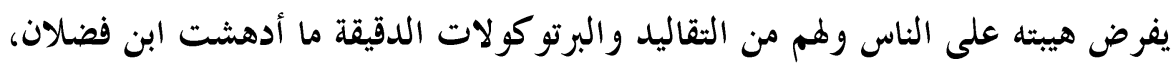

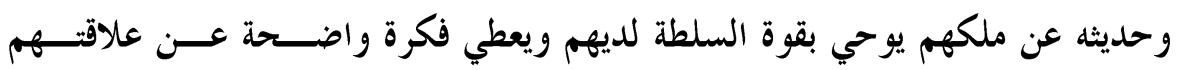

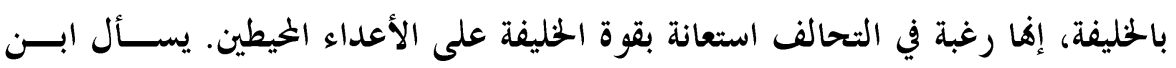
فضلان الملك عن سبب طلبه المال من الحخليفة بالرغم من ثراء دولثه، فيرد عليه أنه تبرّكّك

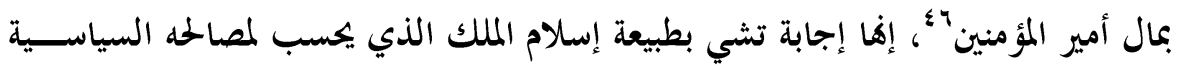

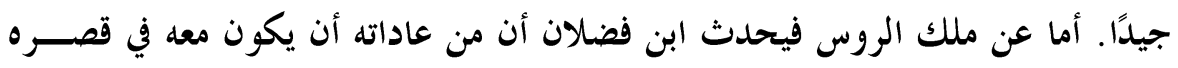

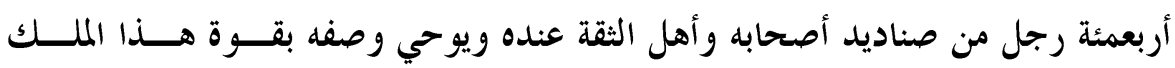

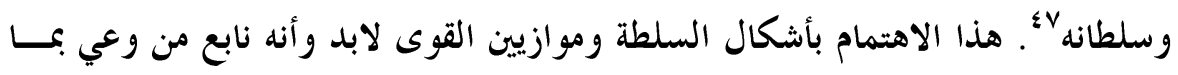

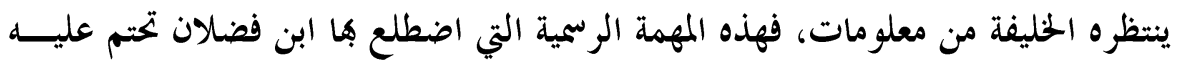

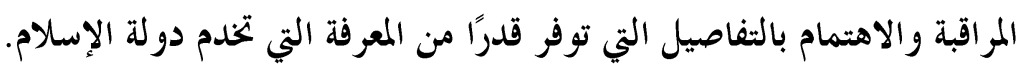

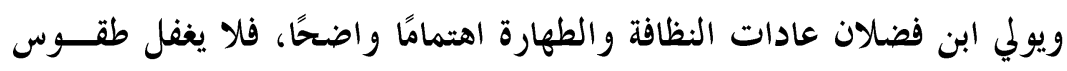
القبيلة في الاغتسال ونظافتهم بشكل عام، ونجده يتحدث عن علاقة قبت وبيلة الغزية بالماء في

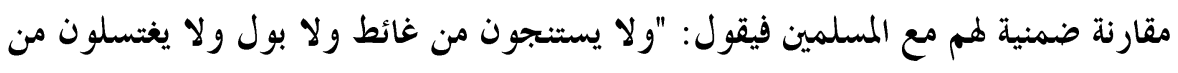

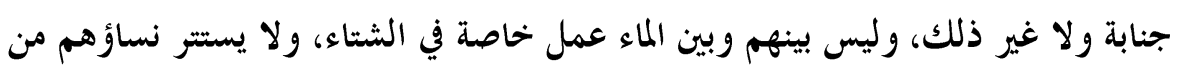

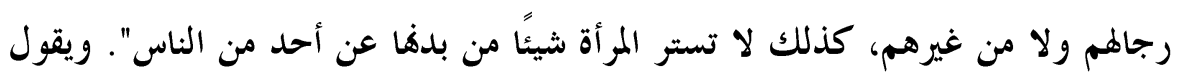

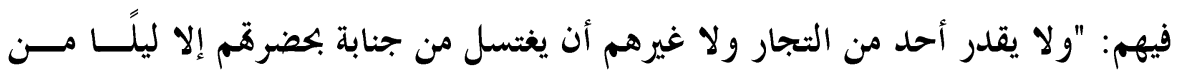

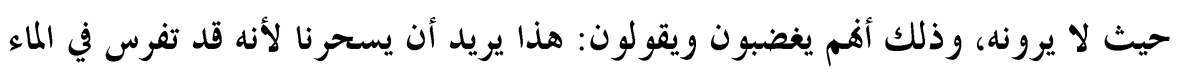

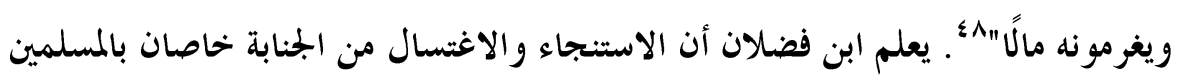


ومع ذلك يتوقع منهم فعلهما، ثم يذكر أفم يغضبون ممن يقترب من الماء دون أن يقـــدم

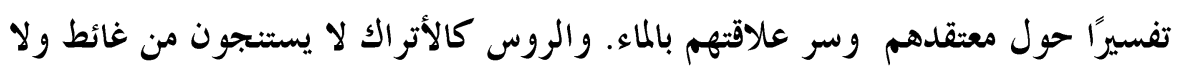

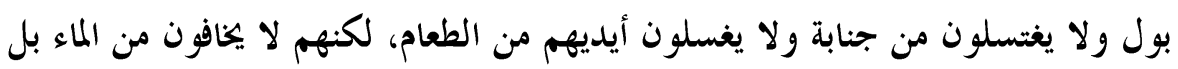

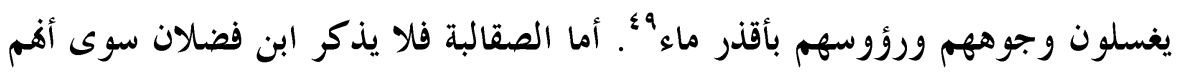

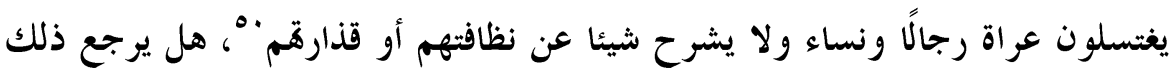

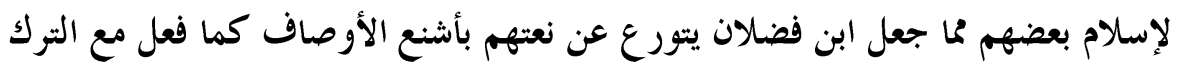

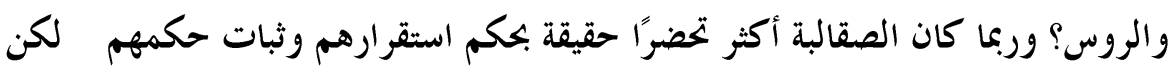

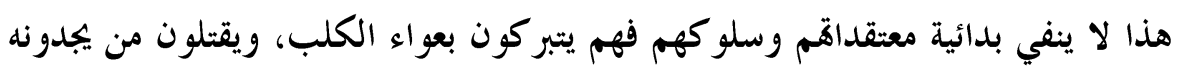

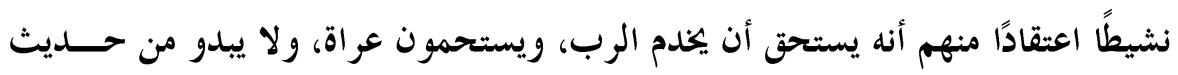

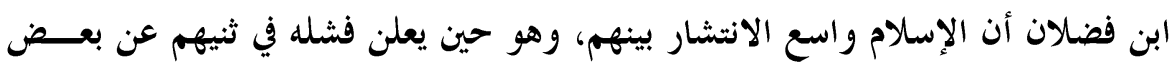

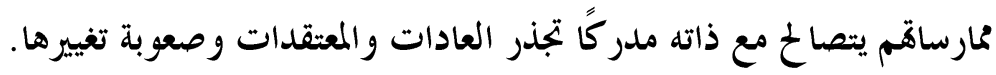

وفي رؤيته للآخر يلتفت ابن فضلان إلى عادات القبيلة في الزواج والمهر وموقفهم من الزنا واللواط كجزء من صورقم الحضارية وعلاقاقم الإنسانية، ويحكيها كما شاهدها

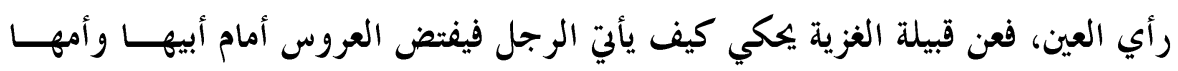

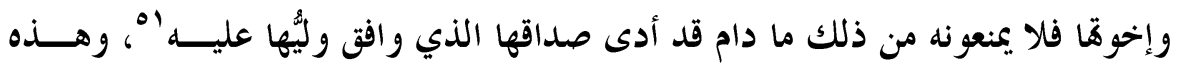

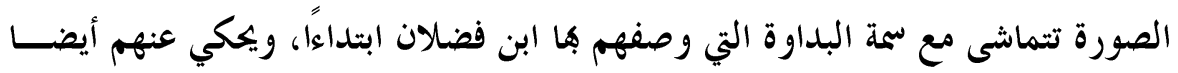

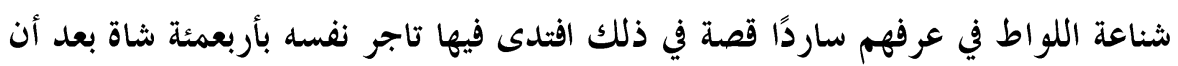

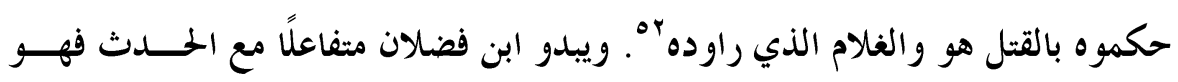

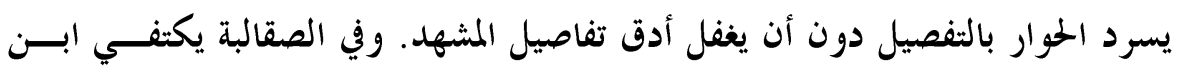

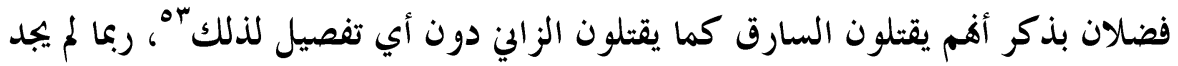

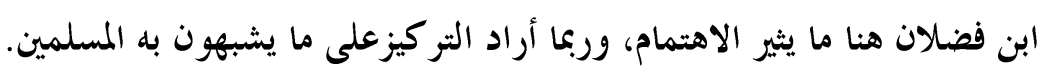
ويبدو ابن فضلان مأخوذًا بطقوس الموت والدفن عند القبائل، يسردها بصــورة

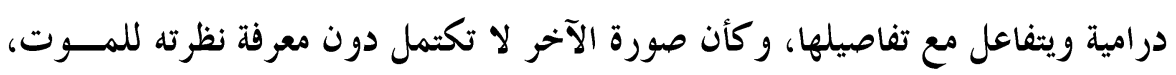

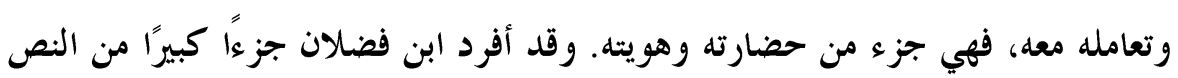

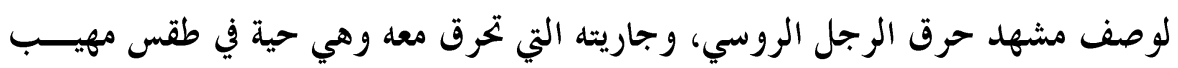


يثير الحزن والثفقة، وهم يعتقدون أن الحرق يأخذه سريعًا للجنة بدل أن تأكله الهـــوام

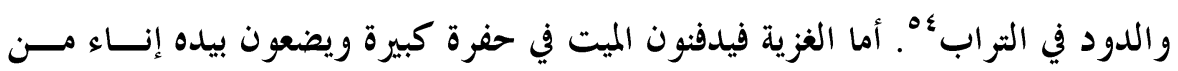

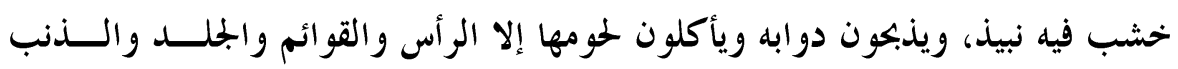

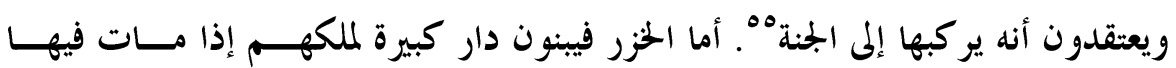

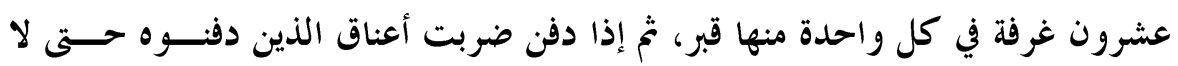

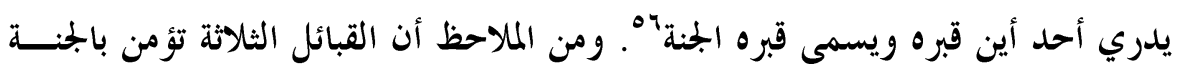

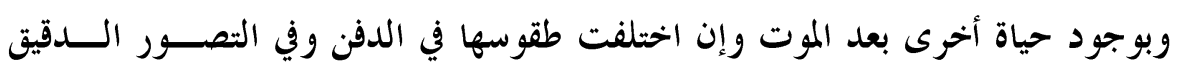
لكلانتقال للحياة الأخرى.

ومن مفردات التفاعل بين قبيلة ما وبين الآخر الغريب عادات الضيافة والاستقبال

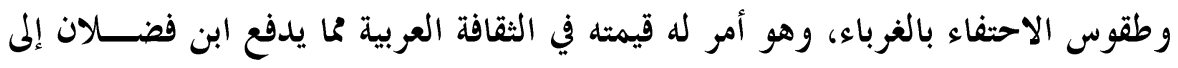
التوقف عنده والاهتمام بسرد عادات الضيافة عند القبيلة التي يتزل فيها، وطريقة تعاملهم

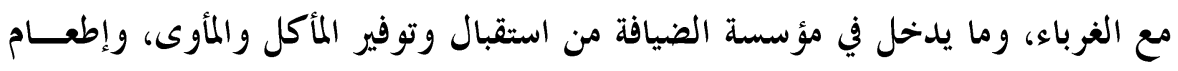

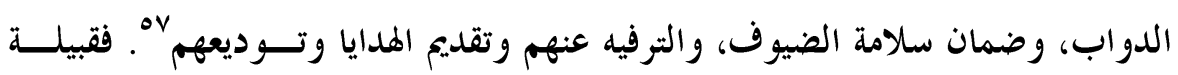

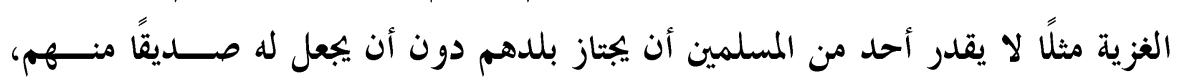

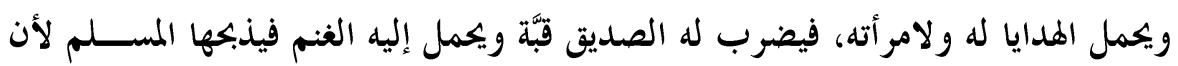

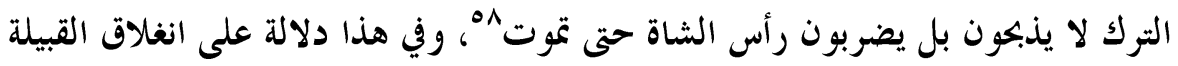

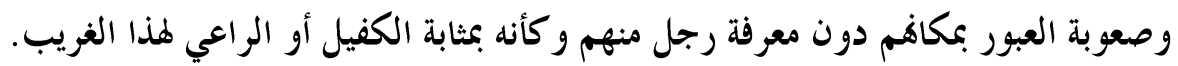

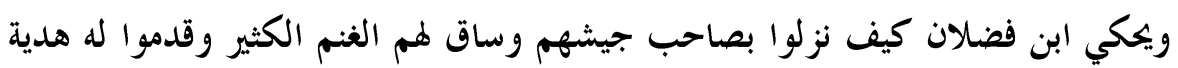

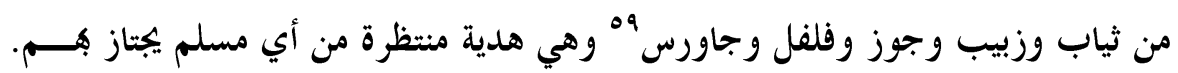

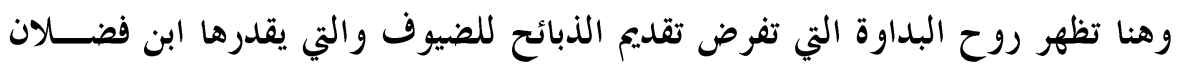

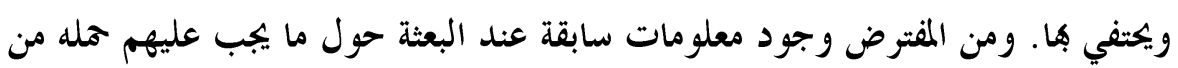

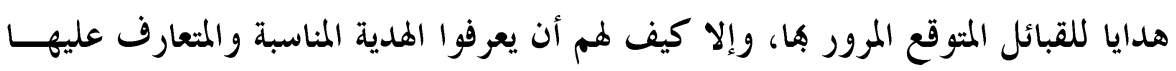

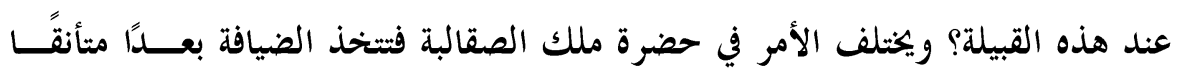
برتو كوليَّا، يحكي ابن فضلان مشهد تناول الطعام فيقول: " فلما كان بعد ساعة وجه إلينا

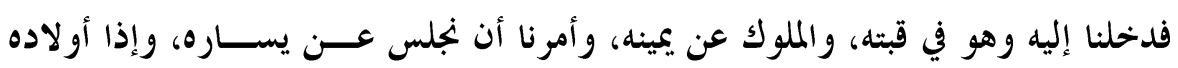


جلوس بين يديه، وهو وحده على سرير مغشى بالديباج الرومي، فدعا بالمائدة فقــدمت

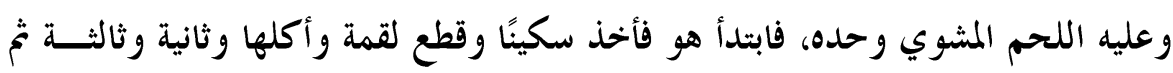
احتز قطعة دفعها إلى (سوسن) الرسول، فلما تناولها جاءته مائدة صغيرة فجعلت بين يدئه

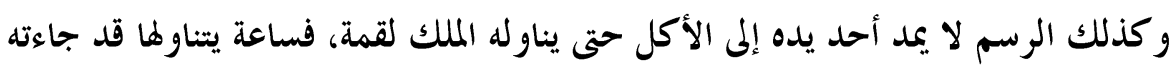

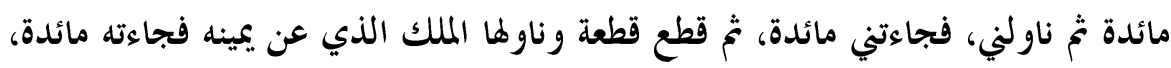

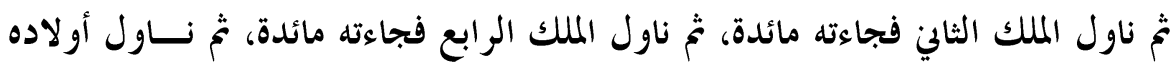

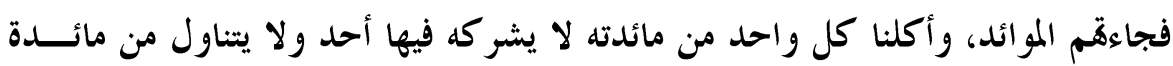

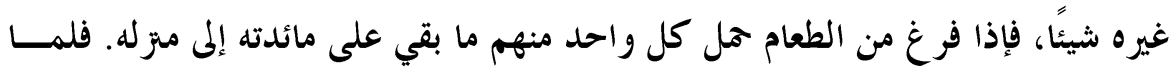

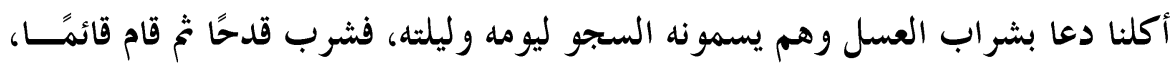

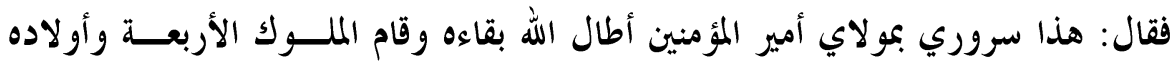

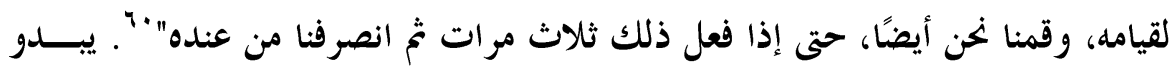

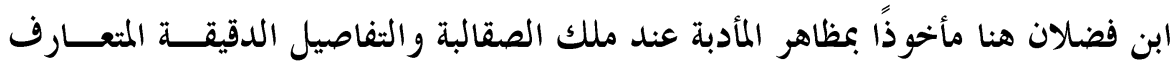
عليها بينهم في حضرة الملك، مما يوحي بهيبته وتنظيمهم ودقتهم وسمة التحضر لديهم. وفي

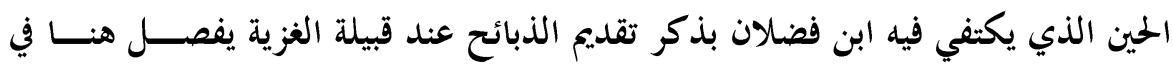

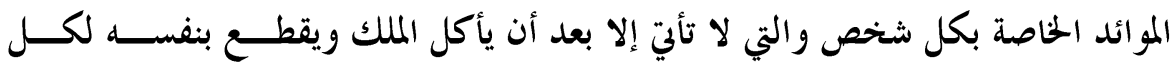
شخص، ويحتفي ابن فضلان حتى بالشر اب وبعبار كة الملك. وهكذا نجد الأنا عند ابن فضلان تتفاعل مع الآخر المتعدد في بيئته وثقافته تفاعلًا

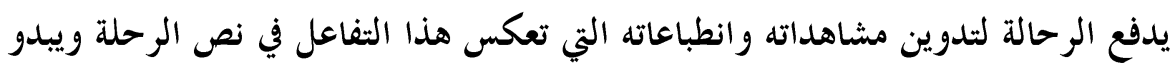

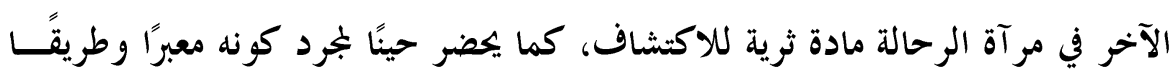

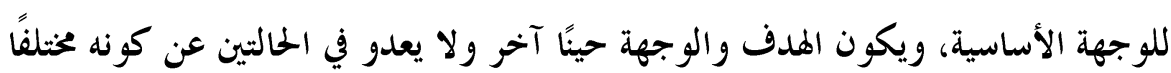
في وجوده و كينو نته يستحق الاكتشاف والوصف. 


\section{الحـــاتــــة}

ينتمي هذا النص إلى أدب الرحلة الذي هو بطبيعته ديناميكي ومفتوح يستمد من النيان

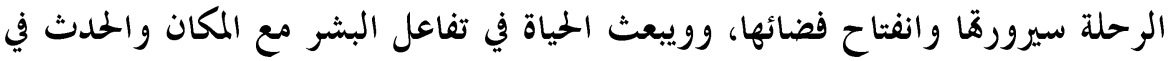

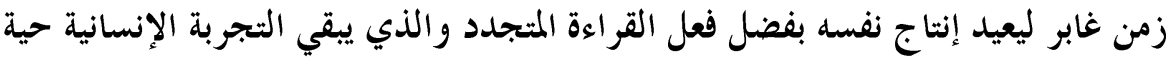

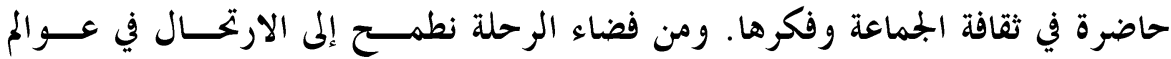

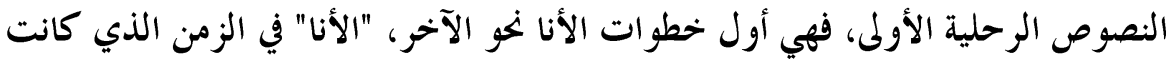

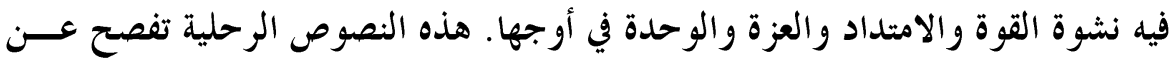
الكثير وتنظر من الباحثين الكثير.

لقد أفضت رحلة البحث عن تجليات الوعي في ثنايا السرد إلى اكتشاف أفكسار

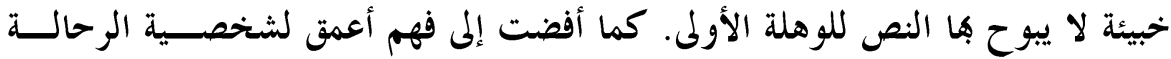

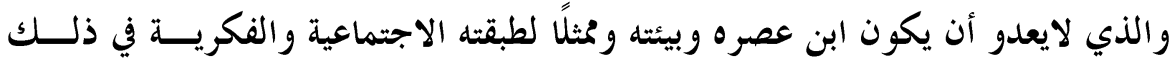

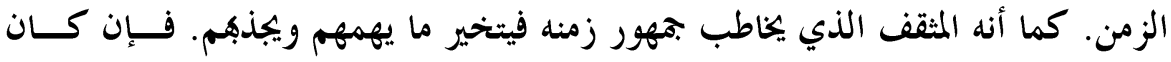
النص في بنيته السطحية يحكي عن الروس والصقالبة والأتراك، فهو في بنيته العميقة يحكي

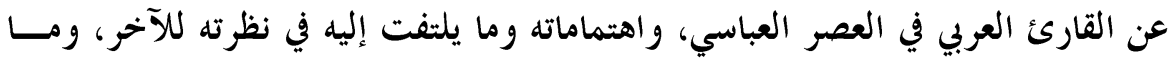
أساليب السرد التي تناسب ذوقه وتشده.

وتو صل التحليل إلى تجليات علاقة الالتحام بين الوعي والسرد، فعلـى مســتوى

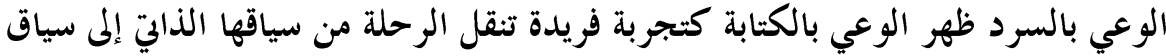

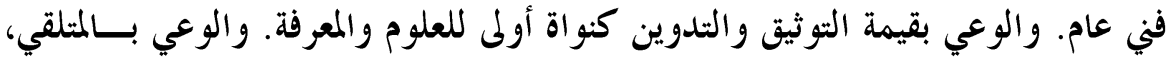

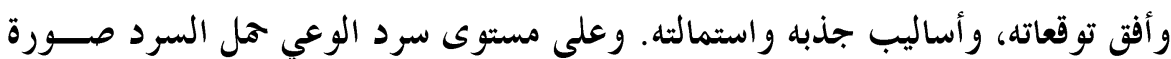

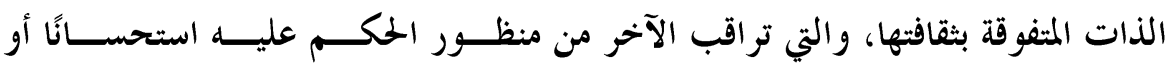

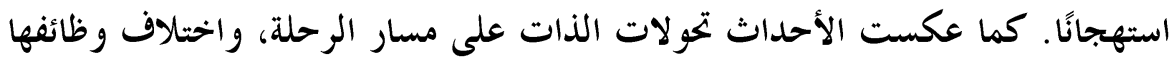
وموقعها من الحدث. أما على مستوى الوعي بالآخر فقد أفصح السرد عن المظاهر الستي

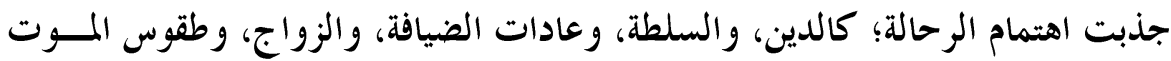


والدفن. وذلك لما تحمله من قيمة في الثقافة العربية، فهي عند العربي الصورة الأصسـدق لموية شعب ما وحضارته.

ومن هنا تتأكد ضرورة تكريس مزيد من البحث والتناول لمثل هذه النصوص التي

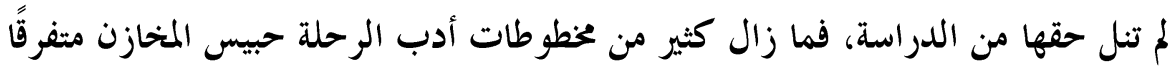
في البلدان. وما حُققق منها يحتاج إلى مزيد من التناول من حيث أن نص الرحلة نص ثري

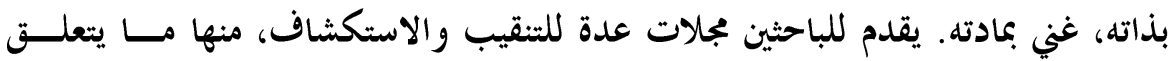

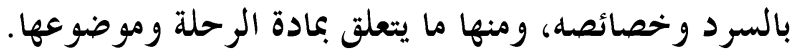
ومن المفيد هنا أن نشير إلى أننا اخترنا النسخة التي حققها الأستاذ شاكر لعسيبي

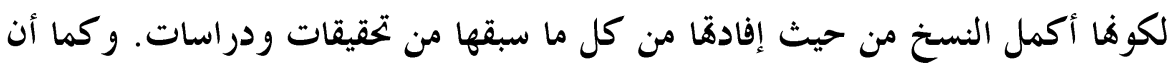
هناك بعض الخاولات الواضح عدم دقتها وأمانتها في إخراج الرحلة ونقلها، حيث ظهرت

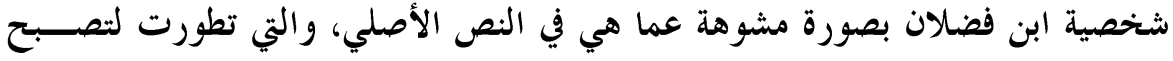

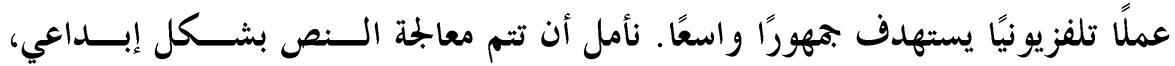
وإخر اجه إلى آفاق أوسع وأرحب، ليصل إلى المتلقي العربي وغيره كعمل مشاهد أو مقروء بصورة جذابة وأمينة. 


\section{الهو امش:}

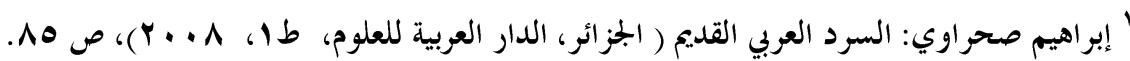

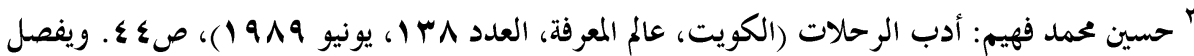
الكتاب في القيمة الاثنوغرافية للرحلات موردا أمثلة من الرحلات العات العربية والغربية.

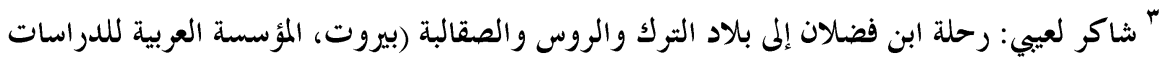

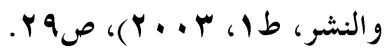

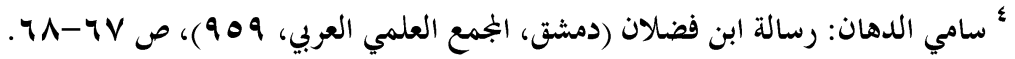

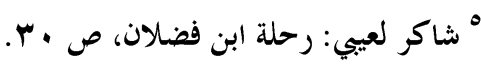

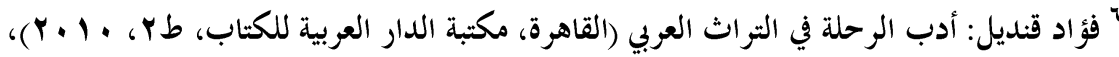
ص

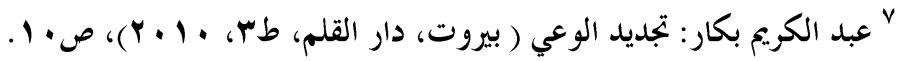

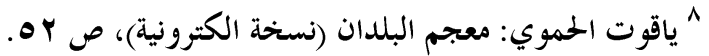

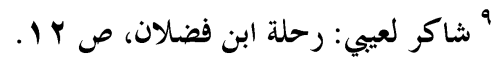

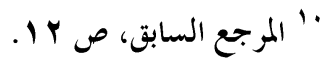

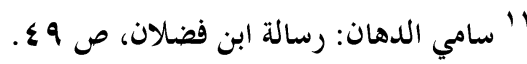

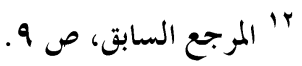

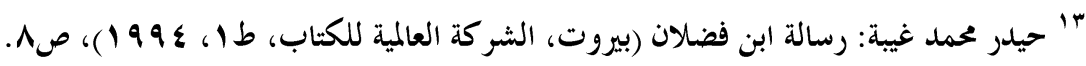

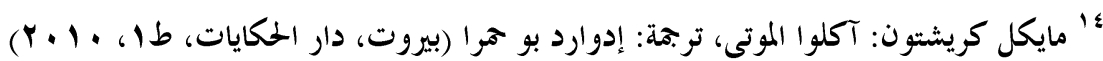

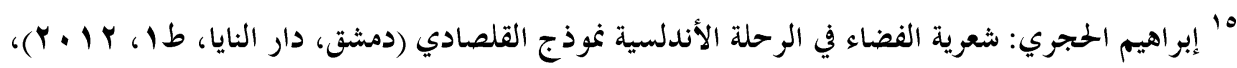

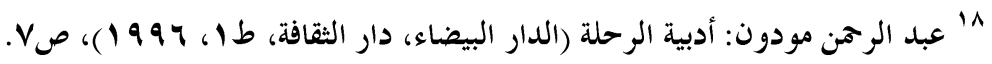

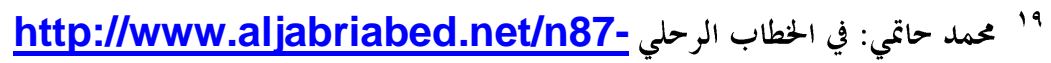

05hatimi.htm

• ب أحد عبد العظيم وآخرون: المنهج الموضوعي في النقد الأدبي ثيمة الرحلة في السرد والشعر نموذجا

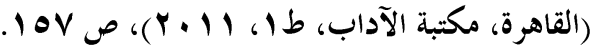

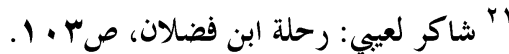




$$
\begin{aligned}
& \text { rrr }
\end{aligned}
$$

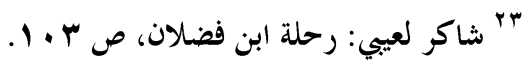

$$
\begin{aligned}
& \text { צ' الأسبلة: هي مقدم اللحية. } \\
& \text { ro البوستين: العباءة أو المعطف المصنوع من الجلد. } \\
& \text { Tr شاكر لعيبي: رحلة ابن فضلان، ص VV TV. }
\end{aligned}
$$

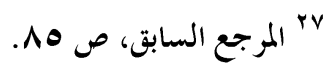

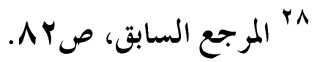

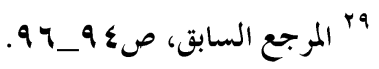

• "أندريه ميكيل: جغر افية دار الإسلام البشرية حتى منتصف القرن الحادي عشر، ترجة: إبراهيم خوري

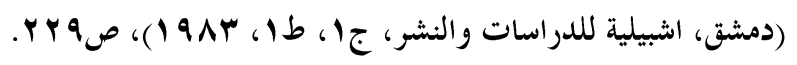

آس يرى ميكيل أن الرسالة هي النوع الأدبي الأقرب إلى نص رحلة ابن فضلان من حيث طبيعثها وخصائصها.

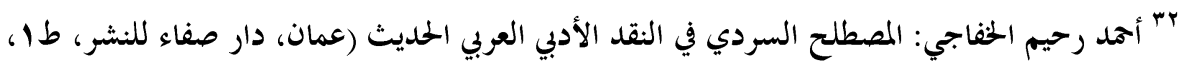

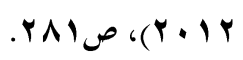

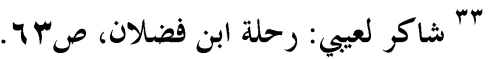

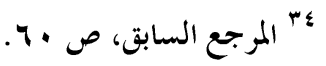

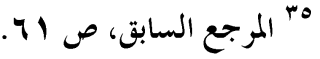

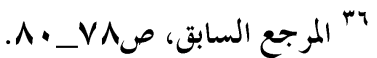

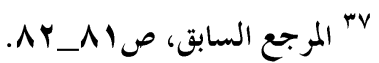

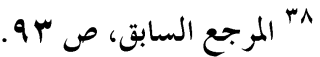

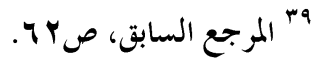

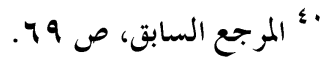

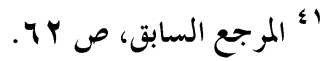

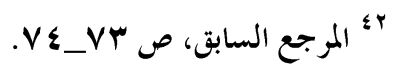

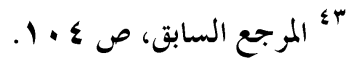

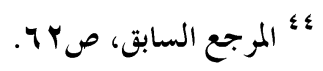

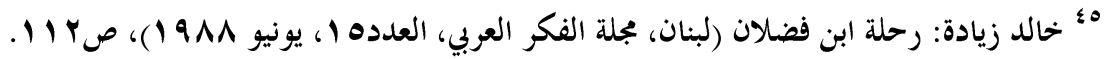

$$
\begin{aligned}
& \text { Tء شاكر لعيبي: رحلة ابن فضلان، صوه9 } 9 .
\end{aligned}
$$

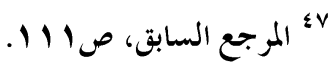

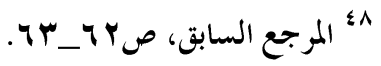




$$
\begin{aligned}
& \text { 9؛ المرجع السابق، ص س • 1. }
\end{aligned}
$$

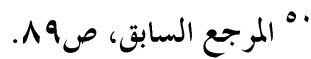

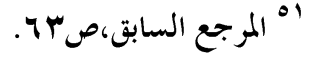

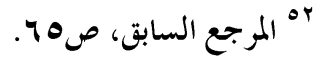

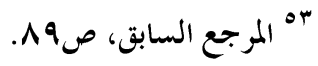

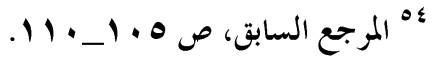

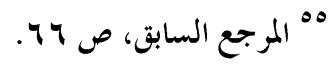

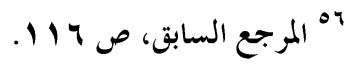

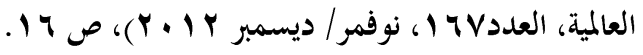

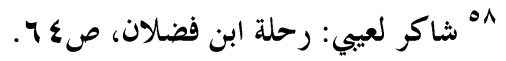

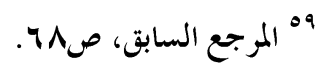

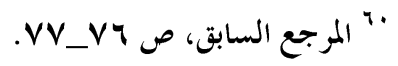

Vo ايداريك كوتشكونوف: طقوس الضيافة في الحضارة القرغيزية الثقليدية والحديثة (الكويت، مجلة الثقافة 


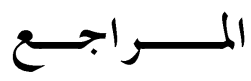

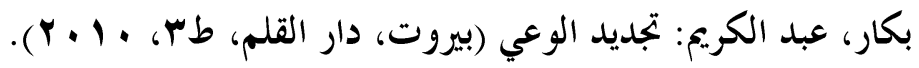

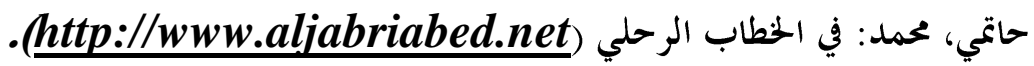
الحجري، إبراهيم: شعرية الفضاء في الرحلة الأندلسية نموذج القلصادي (دمشق، دار النايــا، ط.

الحموي، ياقوت: معجم البلدان (نسخة الكترونية). خفاجي، أحمد رحيم: المصطلح السردي في النقد الأدبي العربي الحديث (عمـــان، دار صــفاء

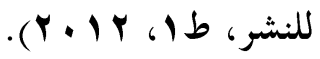

الدهان، سامي: رسالة ابن فضلان (دمشق، البحمع العلمي العربي، وه9 9 9).

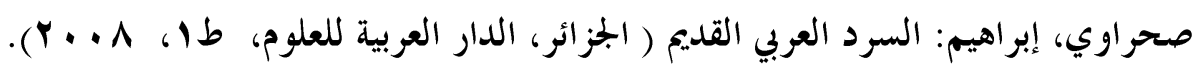

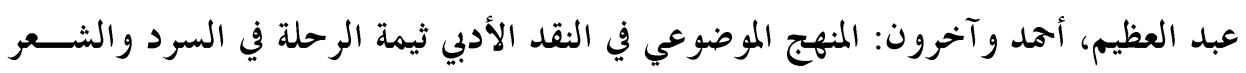

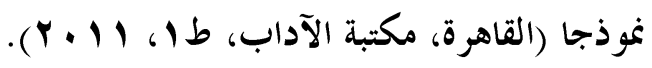

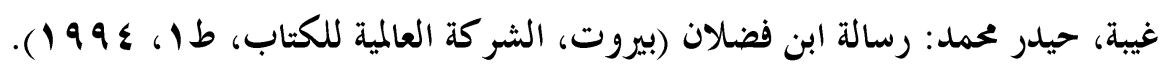

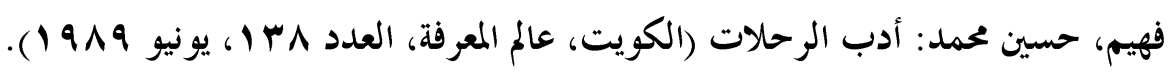

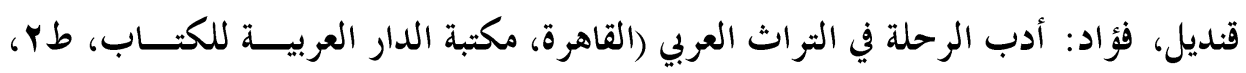
$\cdot(r \cdot 1$.

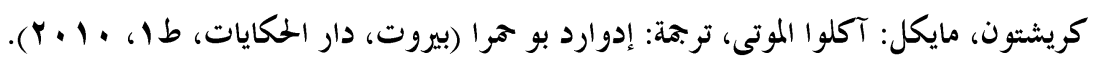

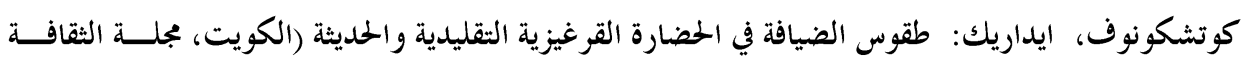

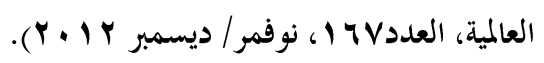

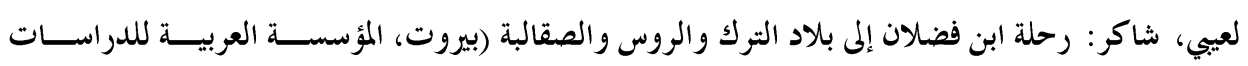

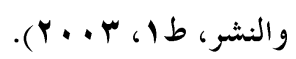

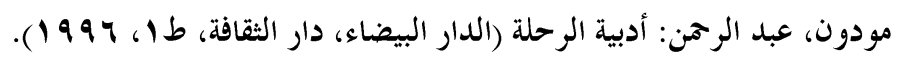

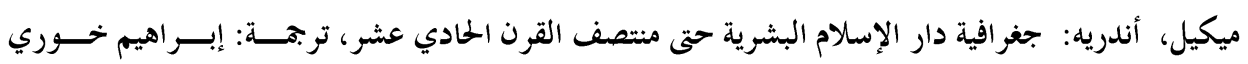

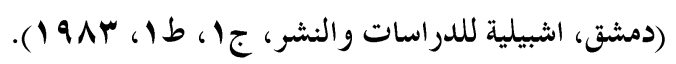

